\title{
DEBT AND DEPTH OF RECESSIONS
}

Donghyun Park, Kwanho Shin, and Shu Tian

\section{N0.579 ADB ECONOMICS \\ April 2019 \\ WORKING PAPER SERIES}


ADB Economics Working Paper Series

\section{Debt and Depth of Recessions}

Donghyun Park, Kwanho Shin, and Shu Tian

No. 579 | April 2019
Donghyun Park (dpark@adb.org) is principal economist and ShuTian (stian@adb.org) is economist in the Economic Research and Regional Cooperation Department, Asian Development Bank (ADB). Kwanho Shin (khshin@korea.ac.kr) is professor in the Department of Economics, Korea University.

This paper was initially prepared for the Asian Development Outlook (ADO) 2018 Update theme chapter on

Maintaining Stability amid Heightened Uncertainty. We thank Abdul Abiad and other workshop participants at the ADO theme chapter midterm workshop on 30-31 May 2018 for their comments. We also thank Jaeyoung Yoo for excellent research assistance. 
(C) 2019 Asian Development Bank 6 ADB Avenue, Mandaluyong City, 1550 Metro Manila, Philippines

Tel +632632 4444; Fax +6326362444

www.adb.org

Some rights reserved. Published in 2019.

ISSN 2313-6537 (print), 2313-6545 (electronic)

Publication Stock No. WPS190126-2

DOI: http://dx.doi.org/10.22617/WPS190126-2

The views expressed in this publication are those of the authors and do not necessarily reflect the views and policies of the Asian Development Bank (ADB) or its Board of Governors or the governments they represent.

ADB does not guarantee the accuracy of the data included in this publication and accepts no responsibility for any consequence of their use. The mention of specific companies or products of manufacturers does not imply that they are endorsed or recommended by ADB in preference to others of a similar nature that are not mentioned.

By making any designation of or reference to a particular territory or geographic area, or by using the term "country" in this document, $A D B$ does not intend to make any judgments as to the legal or other status of any territory or area.

This work is available under the Creative Commons Attribution 3.0 IGO license (CC BY 3.0 IGO)

https://creativecommons.org/licenses/by/3.o/igo/. By using the content of this publication, you agree to be bound by the terms of this license. For attribution, translations, adaptations, and permissions, please read the provisions and terms of use at https://www.adb.org/terms-use\#openaccess.

This CC license does not apply to non-ADB copyright materials in this publication. If the material is attributed to another source, please contact the copyright owner or publisher of that source for permission to reproduce it. $\mathrm{ADB}$ cannot be held liable for any claims that arise as a result of your use of the material.

Please contact pubsmarketing@adb.org if you have questions or comments with respect to content, or if you wish to obtain copyright permission for your intended use that does not fall within these terms, or for permission to use the ADB logo.

Corrigenda to ADB publications may be found at http://www.adb.org/publications/corrigenda.

Notes:

In this publication, “\$” refers to United States dollars.

ADB recognizes "Korea" as the Republic of Korea.

The ADB Economics Working Paper Series presents data, information, and/or findings from ongoing research and studies to encourage exchange of ideas and to elicit comment and feedback about development issues in Asia and the Pacific. Since papers in this series are intended for quick and easy dissemination, the content may or may not be fully edited and may later be modified for final publication. 


\section{CONTENTS}

TABLES AND FIGURES

ABSTRACT

I. INTRODUCTION

II. DATA AND SUMMARY STATISTICS 3

III. EMPIRICAL METHODOLOGY 6

$\begin{array}{lr}\text { IV. } & \text { EMPIRICAL RESULTS }\end{array}$

$\begin{array}{ll}\text { V. CONCLUSION } & 25\end{array}$

$\begin{array}{ll}\text { APPENDIX } & 27\end{array}$

$\begin{array}{lr}\text { REFERENCES } & 29\end{array}$ 


\section{TABLES AND FIGURES}

\section{TABLES}

$1 \quad$ Summary Statistics $\quad 5$

2 Dynamic Correlations of Debt Increments 6

$3 \quad$ Summary Statistics at Peaks $\quad 7$

$4 \quad$ Depth of Recessions in Advanced Economies after Normal versus Financial Peaks 11

5 Depth of Recessions in Advanced and Emerging Market Economies after Normal 13

6 Depth of Recessions in Advanced Economies after Household versus Corporate 15

7 Depth of Recessions in Advanced and Emerging Market Economies after Household 18 versus Corporate Financial Peaks

8 Depth of Recessions and Fiscal Policy Space 20

A1 Advanced and Emerging Market Economies Used in the Sample 27

A2 Definitions of Variables and Data Sources 28

\section{FIGURES}

1 Dynamics of the Ratio of Debts to Gross Domestic Product, 1990-2016 4

2 Ratio of Public Debt to Gross Domestic Product versus Depth of Recession in Output 24 Interest Rates, and Cyclical Credit 


\begin{abstract}
This paper empirically investigates the relationship between the speed of buildup of private debt (household and corporate) and the depth of recessions. To do this, we differentiate between financial recessions and normal recessions on the basis of how quickly their private debt builds up. In addition to output recessions, we look at consumption and investment recessions. We find that financial recessions are deeper than normal recessions in advanced economies-and the differences become even more pronounced when emerging market economies are added to the sample. Our evidence suggests that a buildup in corporate debt is especially damaging for emerging markets during financial recessions. A higher ratio of debt to gross domestic product-in other words, less fiscal spaceexacerbates recessions only beyond a certain threshold level, suggesting a nonlinear effect. We find that the buildup of corporate debt-and not just household debt-can worsen recessions, especially in emerging market economies.
\end{abstract}

Keywords: business cycle, corporate debt, fiscal space, government debt, household debt, private debt, recessions

JEL codes: E32, E44, G01 


\section{INTRODUCTION}

The Great Recession triggered by the global financial crisis (GFC) underlines the danger of recessions driven by financial crises. Indeed, some of the countries hit by the GFC have yet to fully recover. The severity of recessions that coincided with booms and busts of financial cycles led to studies examining whether recessions associated with financial busts tend to be deeper than other recessions. Claessens, Kose, and Terrones (2012) find strong links between business and financial cycles, as well as the pronounced severity and persistence of recessions accompanying busts in house and equity prices. Jordà, Schularick, and Taylor (2013) find that recessions caused by financial crises are costlier than normal recessions, and that credit-intensive expansions tend to be followed by deeper recessions. Romer and Romer (2017a) find that the decline in output following a financial crisis is significant and persistent.

The scholarship on this mostly looks at financial recessions caused by financial crises or asset price busts. Mian, Sufi, and Verner (2017), however, find that an increase in private debt, particularly household debt, generally predicts lower gross domestic product (GDP) growth in the medium term. They argue that if the neglect of downside risks by lenders is a main driver of supply shocks, then increases in credit will eventually have negative consequences. They provide compelling evidence that credit supply shocks rather than demand shocks play a bigger role in private debt expansion. Cecchetti, Mohanty, and Zampolli (2011) also find that both private and public debt exceeding certain threshold levels can drag down growth - and the literature on this is huge. Park, Shin, and Tian (2018) categorize recessions on the basis of the buildup speed of private debt, and find that recessions associated with debt buildups are more damaging than those without debt buildups. Since emerging market economies (EMEs) did not experience debt deleveraging even after the GFC, these findings are a cause for concern. Bernardini and Forni (2017) find that the buildup of private debt also exacerbates the severity of recessions in EMEs, and that rapid public debt buildups are related to even deeper recessions in EMEs than in advanced economies (AEs).

Recessions associated with financial crises or rapid financial buildups are more severe than other normal recessions. But across the different types of recessions there is considerable variation in their severity. Romer and Romer (2017a) emphasize the extent of financial distress as a determinant of this variation. Park, Shin, and Tian (2018) find that financial development mitigates the volatility of booms and busts created by debt buildups. Romer and Romer (2017b) emphasize the impact of macroeconomic policies, particularly monetary and fiscal policy space before financial distress, on the trajectories of crises. For example, if the public debt-GDP ratio (a measure of fiscal space) is relatively low, fiscal policy can be used more aggressively to cushion the decline in output.

This paper defines the depth of recessions as the annual percentage decline from the peak of the cyclical part of GDP to the trough of the subsequent recession, and examines how the depth of recessions is influenced by buildups of private debt. Following Park, Shin, and Tian (2018), we divide recessions into two types: financial and normal recessions. If the annual percentage increase in private debt-which consists of household and corporate debt buildups during the preceding expansion-is greater than the sample median, then the ensuing recession is defined as a financial recession and otherwise as a normal recession. As a robustness check, we use quartiles to define normal recessions (that is, if the accumulation speed is lower than the bottom quartile) and financial recessions (if it is higher than the top quartile). We compare the depth of recessions between the two types of recessions. Since our definition of financial recessions does not necessarily coincide with crises, we 
examine how financial recessions that coincide with crises differ from those that do not. We also examine how the level of public debt influences the severity of both types of recessions.

This paper contributes to the literature on these issues in three ways. First, while most research focuses on AEs, we include as many EMEs as possible in the sample, and compare the two in terms of depth of recessions, particularly financial recessions. We further distinguish between household and corporate debt buildups in assessing the depth of financial recessions. For this, we use the HodrickPrescott filter to extract business cycles. For fast-growing EMEs, the more popular Bry-Boschan algorithm method, which defines downswings as negative GDP growth of even just 1 year, may not be appropriate (Bry and Boschan 1971). ' Second, we measure the depth of recessions not only by falls in output but also by declines in consumption and investment. Since there are more instruments for smoothing consumption than for output, the depth of consumption recessions may show different patterns. Third, we investigate the role of fiscal space in mitigating the depth of recessions; here, we allow for a nonlinear effect. While the nonlinear impact of public debt levels on growth has been extensively investigated, the nonlinear impact of fiscal space on the depth of recessions has not been tested.

The major findings are as follows. For AEs, financial recessions are deeper at statistically significant levels than normal recessions for output and investment, but not for consumption. If EMEs are included in the sample, the difference in the severity of financial and normal recessions is larger for output and investment, and becomes statistically significant even for consumption in some specifications. These findings are generally true and even stronger when we use quartiles to define financial and normal recessions. The findings also hold for financial recessions that do not coincide with crises. These results indicate that private debt buildups can be even more damaging to EMEs, which have fewer instruments to smooth consumption. In line with Claessens, Kose, and Terrones (2012), we find that trade openness mitigates recessions, but financial openness aggravates them.

When we further distinguish between financial recessions that are driven by household rather than corporate debt buildups, we find that recessions driven by household debt buildups are generally deeper than those driven by corporate debt buildups in AEs, a finding in line with the literature. But when we include EMEs in the sample, recessions driven by corporate debt buildups are deeper in some specifications, suggesting that corporate debt buildups are more damaging to EMEs. ${ }^{2}$ We find that fiscal space affects the severity of recessions only after the public debt-GDP ratio reaches a threshold of $57.9 \%$. When that level is exceeded, recessions become deeper as the ratio increases. We find this for only financial recessions, which suggests that fiscal policy is more effective for tackling financial distress. In addition, we find that this nonlinear effect of fiscal space is especially evident in EMEs, and that fiscal space matters more when recessions are driven by corporate debt buildups.

The rest of the paper is organized as follows. Section II explains the data and summary statistics of variables. Section III explains the empirical methodology. Section IV discusses the empirical results, and section $\vee$ draws conclusions.

\footnotetext{
1 Section III on the empirical methodology explains the difference between the Hodrick-Prescott filter and the BryBoschan algorithm.

2 The damaging effect of corporate debt in EMEs is also emphasized in Park, Shin, and Tian (2018).
} 


\section{DATA AND SUMMARY STATISTICS}

This section describes the data used in the empirical analysis and explains the basic summary statistics of the variables. We collect three types of debt data: household debt, nonfinancial corporate debt, and government debt as shares of GDP. The household and nonfinancial corporate debt data are from the Bank for International Settlements (BIS) total credit statistics. ${ }^{3}$ The public debt data are from the International Monetary Fund's World Economic Outlook database, the World Bank's World Development Indicators, and the BIS total credit statistics. ${ }^{4}$ Public debt is the debt of the general government except for seven economies in the sample for which we use the debt of the central government. ${ }^{5}$ The sample has 21 AEs and 17 EMEs for which private household and nonfinancial corporate debt data are available, and 20 AEs and 11 EMEs for which public debt data are available. Appendix Table A1 lists the AEs and EMEs in the sample.

For business cycles, we use annual real GDP per capita from the Penn World Table. We divide real GDP at constant 2011 national prices by population to get value per capita. We also calculate real consumption and investment per capita in a similar way by collecting the data from the Penn World Table. ${ }^{6}$ We collect two asset prices: the housing price index and stock price index. The housing price index is from the BIS' property price database and the Jordà-Schularick-Taylor Macrohistory Database. The stock price index is from the Jordà-Schularick-Taylor Macrohistory Database, and supplemented by Global Financial Data and Bloomberg LP. The descriptions and sources of these variables and other control variables are summarized in Appendix Table A2.

Figure 1 illustrates the dynamics of household, corporate, and public debt as shares of GDP for AEs and Asian EMEs from 1990 to 2016. Both types of debt increased rapidly in AEs before the GFC and stabilized since then. The boom and bust of private debt accumulation are more pronounced for household debt than corporate debt. In contrast, public debt in AEs did not increase before the GFC, but increased quite rapidly after it, reflecting fiscal expansion.

Figure 1 shows the dynamics of private and public debt in EMEs and in four Asian EMEs. Unlike AEs, EMEs accumulated household and corporate debt more rapidly after the GFC. In fact, the level of corporate debt continued to decrease just before the GFC and then started to grow rapidly after the crisis. While less dramatic, household debt has grown much more rapidly than corporate debt since the 2000s, and continued to do so even after the GFC. Public debt in EMEs also increased after the GFC, but its level was lower in 2016 than in 2003. In the four Asian EMEs, the increase in corporate debt was most pronounced before the Asian financial crisis in 1997. ${ }^{7}$ It plummeted after this crisis, and has not expanded significantly since then. Conversely, while household debt grew rapidly before the Asian financial crisis, it has grown even faster since the early 2000s, including during the GFC. Public debt in the four Asian EMEs is quite low and remained so even after the GFC.

3 In this paper, corporate debt refers to nonfinancial corporate debt.

4 The World Economic Outlook database was used for most countries, with data drawn from October 2017. World Development Indicators were used for six countries, and BIS total credit statistics for the United States (US).

5 Central government debt was used for Guatemala, Indonesia, Jamaica, Mongolia, Nepal, Thailand, and the US.

6 Penn World Table version 9.0 reports only shares and not levels of consumption and investment in output-side real GDP at chained purchasing power parities in 2011 US dollars. Levels are therefore calculated by multiplying shares to outputside real GDP at chained purchasing power parities. But our findings hardly change if we use GDP at constant national prices.

7 The four countries - Indonesia, Malaysia, the Republic of Korea, and Thailand - were the hardest hit by the Asian financial crisis. 
Figure 1: Dynamics of the Ratio of Debts to Gross Domestic Product, 1990-2016

(a) Advanced economies

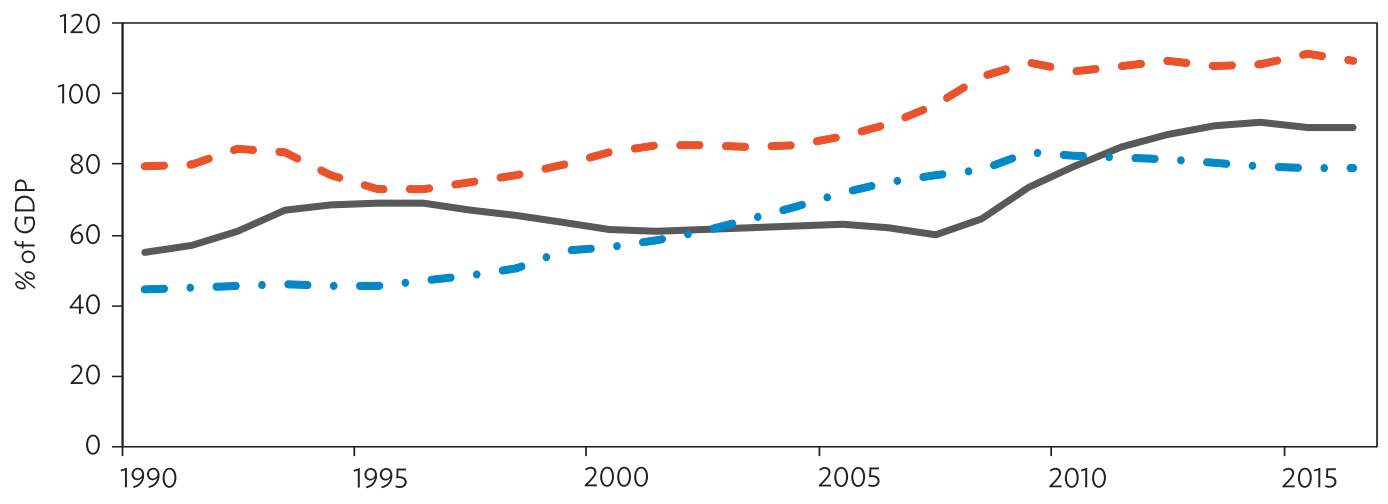

(b) Emerging market economies

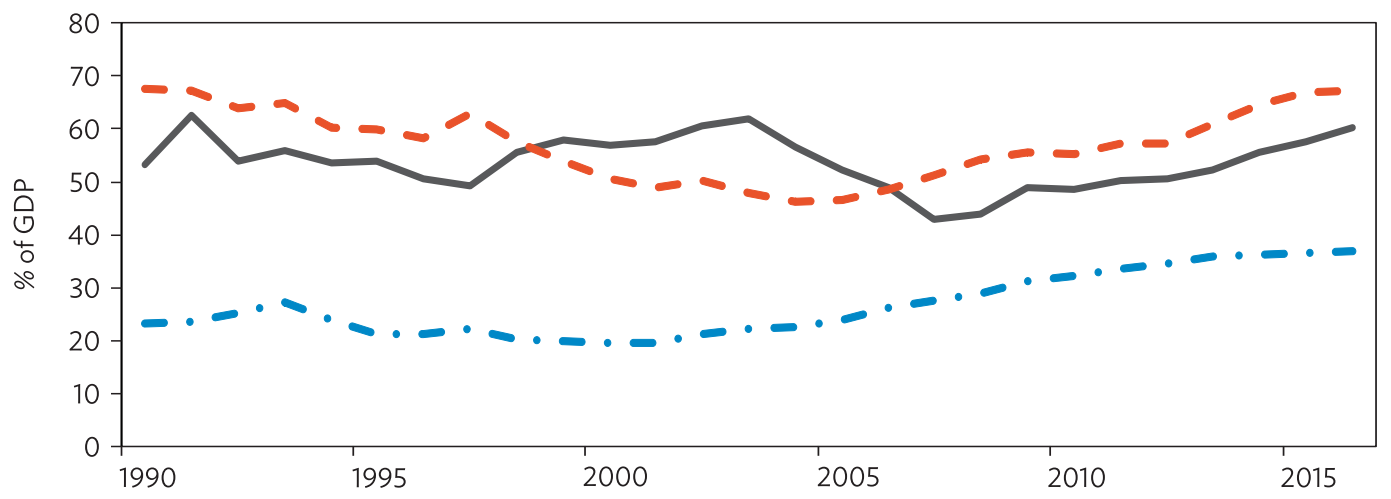

(c) Four Asian emerging market economies

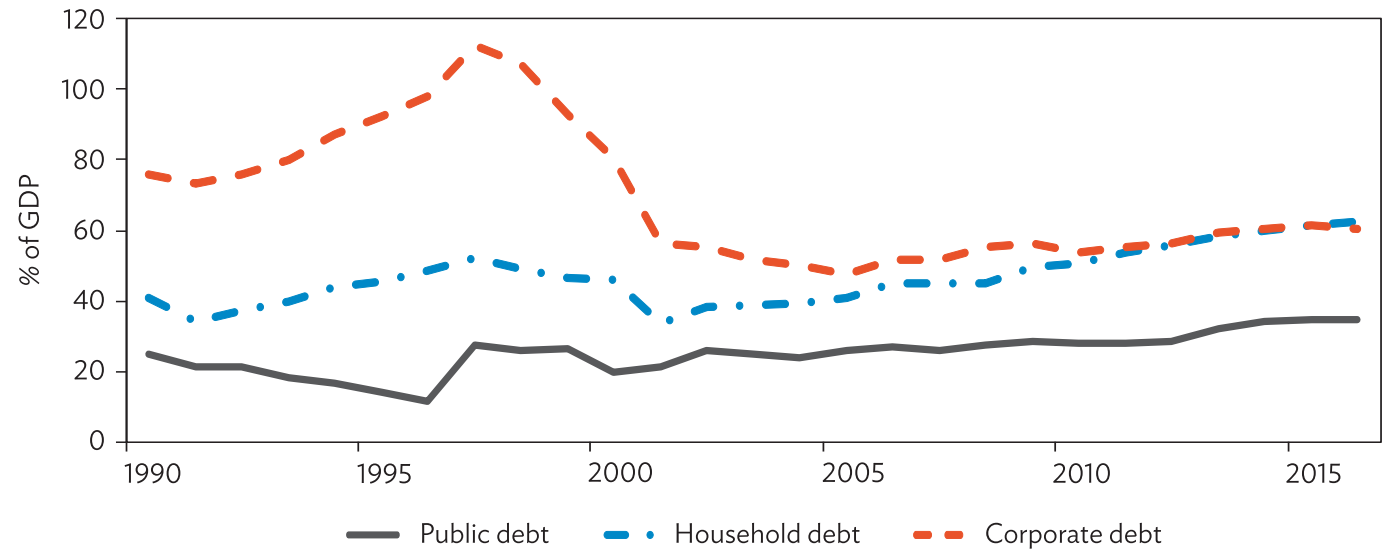

GDP = gross domestic product.

Notes:

1. Debts are denoted as a share of gross domestic product.

2. Appendix Table A1 lists the advanced and emerging market economies. The four Asian emerging market economies are Indonesia, Malaysia, the Republic of Korea, and Thailand.

Source: Authors' calculations. 
Table 1 shows the summary statistics of the debt variables for AEs and EMEs. The dataset is an unbalanced panel of varying sample periods from 1960 to 2014 . $^{8}$ The levels of all three types of debt are higher in AEs than in EMEs. Household debt as share of GDP in AEs is more than twice as high than in EMEs, and corporate debt as a share of GDP is about 1.5 times higher in AEs. The gap between AEs and EMEs is smallest for public debt. For all three types of debt, the speed of accumulation is on average higher in AEs than in EMEs. While the level of public debt on average decreased over time in EMEs, the other types of debts on average have increased over time. The volatility of accumulation speed is higher for corporate debt than for household debt in AEs and EMEs. The volatility of accumulation speed of public debt is similar to that of corporate debt in AEs, but higher than that of corporate debt in EMEs.

Table 1: Summary Statistics

\begin{tabular}{lrrrrrrrrrr}
\hline & \multicolumn{1}{c}{ All Samples } \\
\hline Item & \multicolumn{1}{c}{ Advanced Economies } & \multicolumn{4}{c}{ Emerging Market Economies } \\
\hline & Count & Mean & SD & Min & Max & Count & Mean & SD & Min & Max \\
\hline Private debt & 1,080 & 120.4 & 50.2 & 25.5 & 324.0 & 541 & 75.0 & 48.2 & 10.9 & 278.5 \\
Increment of private debt & 1,059 & 2.3 & 5.7 & -18.6 & 56.3 & 524 & 1.8 & 7.6 & -67.6 & 49.8 \\
Private household debt & 744 & 54.3 & 26.4 & 5.5 & 139.4 & 381 & 25.0 & 20.0 & 0.1 & 84.2 \\
Increment of household debt & 723 & 1.3 & 2.7 & -11.8 & 11.4 & 364 & 1.0 & 2.1 & -6.2 & 9.8 \\
Private corporate debt & 726 & 82.7 & 29.8 & 25.0 & 220.0 & 381 & 54.2 & 32.6 & 11.4 & 212.9 \\
Increment of corporate debt & 705 & 1.3 & 5.2 & -19.1 & 46.4 & 364 & 0.8 & 5.4 & -20.4 & 28.0 \\
Public debt & 631 & 64.3 & 36.0 & 9.7 & 242.1 & 779 & 52.7 & 30.9 & 3.7 & 232.8 \\
Increment of public debt & 611 & 1.5 & 5.1 & -17.5 & 25.8 & 734 & -0.2 & 9.4 & 109.2 & 70.4 \\
\hline
\end{tabular}

SD = standard deviation.

Notes: Private, household, corporate, and public debt are defined as a ratio to gross domestic product. Increment is the annual increase in the ratio. Appendix Table $\mathrm{A} 1$ lists the advanced and emerging market economies.

Source: Authors' calculations.

Table 2 shows dynamic correlation coefficients of annual increases in the three types of debt as shares of GDP for AEs and EMEs. We report the median correlations, and standard deviations in parentheses. Panel (a) in the table shows the dynamic correlation coefficients between household and corporate debts. The contemporaneous correlation coefficient is higher in AEs than in EMEs. Household debt is leading corporate debt in EMEs in the sense that the correlation between household and corporate debt 1 year forward is highest in EMEs. In contrast, there is some evidence of corporate debt leading household debt in AEs. Panels (b) and (c) show the dynamic correlations between household and public debt and between corporate debt and public debt. In general, the table shows that household and corporate debt have negative correlations with public debt, suggesting that fiscal policy is more active when private debt grows more slowly. Interestingly, however, the forward values of public debt are more correlated with household and corporate debts in EMEs.

8 The reason the sample period ends in 2014 is that GDP data collected from the Penn World Table cover up to 2014. 
Table 2: Dynamic Correlations of Debt Increments

\begin{tabular}{|c|c|c|c|c|c|c|c|}
\hline \multicolumn{8}{|c|}{ (a) Correlation with $\Delta \boldsymbol{h} \boldsymbol{h} \boldsymbol{d}_{\boldsymbol{t}}$} \\
\hline Type of Economy & $\Delta \operatorname{corp}_{t-3}$ & $\Delta \operatorname{corp}_{t-2}$ & $\Delta \operatorname{corp}_{t-1}$ & $\Delta \operatorname{corp}_{t}$ & $\Delta \operatorname{corp}_{t+1}$ & $\Delta \operatorname{corp}_{t+2}$ & $\Delta \operatorname{corp}_{t+3}$ \\
\hline Advanced economies & $\begin{array}{l}0.007 \\
(0.19)\end{array}$ & $\begin{array}{l}0.124 \\
(0.19)\end{array}$ & $\begin{array}{r}0.232 \\
(0.24)\end{array}$ & $\begin{array}{r}0.239 \\
(0.24)\end{array}$ & $\begin{array}{r}0.189 \\
(0.26)\end{array}$ & $\begin{array}{r}0.156 \\
(0.27)\end{array}$ & $\begin{array}{l}0.232 \\
(0.21)\end{array}$ \\
\hline Emerging market & -0.114 & 0.054 & -0.086 & 0.171 & 0.171 & 0.225 & 0.131 \\
\hline & $(0.26)$ & $(0.30)$ & $(0.31)$ & $(0.33)$ & $(0.27)$ & $(0.36)$ & $(0.25)$ \\
\hline \multicolumn{8}{|c|}{ (b) Correlation with $\Delta \boldsymbol{h} \boldsymbol{h} \boldsymbol{d}_{\boldsymbol{t}}$} \\
\hline & $\Delta p u b_{t-3}$ & $\Delta p u b_{t-2}$ & $\Delta p u b_{t-1}$ & $\Delta p u b_{t}$ & $\Delta p u b_{t+1}$ & $\Delta p u b_{t+2}$ & $\Delta p u b_{t+3}$ \\
\hline Advanced economies & $\begin{array}{r}-0.403 \\
(0.24)\end{array}$ & $\begin{array}{l}-0.419 \\
(0.20)\end{array}$ & $\begin{array}{r}-0.252 \\
(0.35)\end{array}$ & $\begin{array}{r}-0.042 \\
(0.30)\end{array}$ & $\begin{array}{r}-0.078 \\
(0.22)\end{array}$ & $\begin{array}{r}-0.099 \\
(0.24)\end{array}$ & $\begin{array}{r}0.132 \\
(0.26)\end{array}$ \\
\hline \multirow{4}{*}{$\begin{array}{l}\text { Emerging market } \\
\text { economies }\end{array}$} & -0.122 & -0.121 & -0.125 & -0.258 & 0.168 & -0.056 & 0.163 \\
\hline & $(0.29)$ & $(0.36)$ & $(0.32)$ & $(0.37)$ & $(0.24)$ & $(0.33)$ & $(0.27)$ \\
\hline & \multicolumn{7}{|c|}{ (c) Correlation with $\Delta \operatorname{corp}_{t}$} \\
\hline & $\Delta p u b_{t-3}$ & $\Delta p u b_{t-2}$ & $\Delta p u b_{t-1}$ & $\Delta p u b_{t}$ & $\Delta p u b_{t+1}$ & $\Delta p u b_{t+2}$ & $\Delta p u b_{t+3}$ \\
\hline Advanced economies & $\begin{array}{r}-0.247 \\
(0.27)\end{array}$ & $\begin{array}{r}-0.296 \\
(0.21)\end{array}$ & $\begin{array}{l}-0.310 \\
(0.26)\end{array}$ & $\begin{array}{l}-0.149 \\
(0.23)\end{array}$ & $\begin{array}{r}0.122 \\
(0.26)\end{array}$ & $\begin{array}{l}0.053 \\
(0.25)\end{array}$ & $\begin{array}{r}0.214 \\
(0.24)\end{array}$ \\
\hline \multirow{2}{*}{$\begin{array}{l}\text { Emerging market } \\
\text { economies }\end{array}$} & -0.114 & -0.113 & -0.091 & 0.236 & 0.209 & 0.283 & 0.221 \\
\hline & $(0.20)$ & $(0.28)$ & $(0.30)$ & $(0.35)$ & $(0.22)$ & $(0.26)$ & $(0.18)$ \\
\hline
\end{tabular}

Notes: $\Delta h h d_{t}, \Delta \operatorname{corp}_{t}, \Delta p u b_{t}$ are annual increments of household, corporate, and public debt as a ratio to gross domestic product. Numbers in parentheses are standard errors. Appendix Table A1 lists the advanced and emerging market economies.

Source: Authors' calculations.

\section{EMPIRICAL METHODOLOGY}

In this section, we explain the empirical methodology. To identify peaks and troughs of business cycles, we use the Hodrick-Prescott filter. In Jordà, Schularick, and Taylor (2013) and most other relevant studies, business cycle peaks and troughs are dated using the Bry-Boschan algorithm. Had we used the Bry-Boschan algorithm for EMEs, we would have detected fewer peaks in these economies, because GDP growth is on average higher in EMEs than in AEs. And in the extreme cases of very fast-growing economies, no recessions would have been found using the Bry-Boschan algorithm. To avoid this problem, we use the Hodrick-Prescott filter, and define peaks and troughs as local maxima and minima of cyclical parts derived from the filter. ${ }^{9}$ This shows 147 peaks in AEs and 83 peaks in EMEs. ${ }^{10}$ After identifying peaks and troughs, we define the depth of recessions in GDP by calculating annual percentage changes from the peak of the cyclical parts of GDP to the next trough. By using the same chronology of business cycles, we also define the depth of recessions in consumption and investment by calculating the difference between the cyclical parts at the peak and the trough of consumption and investment, respectively. We use per capita values for GDP, consumption, and investment.

9 Park, Shin, and Tian (2018) also relied on the Hodrick-Prescott filter for the same reason.

10 The numbers of normal peaks and financial peaks in Table 3 do not sum to the total number of peaks because the distinction between normal and financial peaks is made only if the relevant financial debt data are also available. 
After identifying peaks, we distinguish whether they are driven by normal or financial booms. Most studies distinguish between a financial and normal peak whether there was a financial crisis or not after a peak. If there was a financial crisis following a peak, Jordà, Schularick, and Taylor (2013) and most other studies define the peak as a financial peak. Otherwise it is defined as a normal peak. For this approach to be meaningful, it is essential to have an accurate chronology of crisis episodes. It is not easy, however, to define crises for a large sample of countries on a consistent basis." This paper follows Park, Shin, and Tian (2018) and defines financial peaks solely on the basis of the accumulation speed of private debt (the sum of household and corporate debt). If the accumulation speed is higher than the sample median, the peak is defined as a financial peak and otherwise as a normal peak. Although this approach is based on an objective statistical measure, it has drawbacks, since it may not be appropriate to compare the speed of debt accumulation across countries with different financial institutions.

As a robustness check, we adopt stricter cutoff points using quartiles. If the accumulation speed is higher than the top quartile, a peak is defined as a financial peak. If a peak is lower than the bottom quartile, it is defined as a normal peak. Peaks between the top quarter quartile and the bottom quarter quartile are removed so that the distinction between normal and financial peaks becomes sharper. We further distinguish between household and corporate financial peaks by comparing the annual accumulation speed of household and corporate debt buildups. In the boom preceding a financial peak, if the speed of household debt buildup is higher than that of corporate debt, we define the peak as a household financial peak and otherwise as a corporate financial peak.

Table 3 shows the summary statistics of the variables at peaks for AEs (panel $[a]$ ) and for EMEs (panel [b]). Comparing normal with financial peaks, panels (a) and (b) show that relative to GDP, total private, household, and corporate debt are all higher at financial peaks than at normal peaks. As expected, the ratio of household (corporate) debt to GDP is higher at financial peaks driven by household (corporate) debts than peaks driven by corporate (household) debts. Interestingly, the public debt-to-GDP ratio is higher at normal peaks than at financial peaks.

Table 3: Summary Statistics at Peaks

(a) Advanced economies

\begin{tabular}{|c|c|c|c|c|c|c|c|c|c|c|}
\hline \multirow[t]{2}{*}{ Item } & \multicolumn{5}{|c|}{ Normal Peaks } & \multicolumn{5}{|c|}{ Financial Peaks } \\
\hline & Count & Mean & SD & Min & Max & Count & Mean & SD & Min & Max \\
\hline Private debt-GDP ratio & 68 & 116.1 & 55.5 & 28.1 & 301.4 & 68 & 131.3 & 49.5 & 35.8 & 230.7 \\
\hline Household debt-GDP ratio & 46 & 53.3 & 28.7 & 9.9 & 118.3 & 49 & 59.0 & 24.8 & 9.6 & 124.2 \\
\hline Corporate debt-GDP ratio & 45 & 82.4 & 34.9 & 25.0 & 220.0 & 47 & 90.1 & 26.9 & 42.1 & 143.6 \\
\hline Public debt-GDP ratio & 38 & 71.4 & 45.2 & 10.9 & 240.5 & 41 & 53.7 & 25.5 & 9.7 & 109.4 \\
\hline Depth of recession & 63 & -4.4 & 2.7 & -11.7 & -0.6 & 66 & -5.8 & 3.4 & -16.9 & -0.7 \\
\hline Duration of recession & 63 & 3.0 & 1.7 & 1.0 & 9.0 & 66 & 3.3 & 2.0 & 1.0 & 11.0 \\
\hline Trade openness & 65 & 0.65 & 0.37 & 0.10 & 2.1 & 66 & 0.63 & 0.30 & 0.18 & 1.53 \\
\hline Financial openness & 50 & 2.6 & 2.8 & 0.3 & 10.9 & 60 & 3.0 & 3.8 & 0.2 & 26.0 \\
\hline World growth & 68 & 1.4 & 0.8 & -0.9 & 3.1 & 68 & 1.2 & 0.8 & -0.9 & 2.9 \\
\hline $\begin{array}{l}\text { Housing price increase during } \\
\text { expansion }\end{array}$ & 57 & 0.06 & 0.07 & -0.10 & 0.3 & 55 & 0.10 & 0.05 & 0.00 & 0.24 \\
\hline $\begin{array}{l}\text { Stock price increase during } \\
\text { expansion }\end{array}$ & 60 & 0.07 & 0.14 & -0.19 & 0.5 & 65 & 0.09 & 0.10 & -0.19 & 0.31 \\
\hline
\end{tabular}

continued on next page

11 See Romer and Romer (2017a) for the advantages and disadvantages of various approaches for defining financial stress and crisis. 
8 | ADB Economics Working Paper Series No. 579

Table 3 continued

\begin{tabular}{|c|c|c|c|c|c|c|c|c|c|c|}
\hline & \multicolumn{5}{|c|}{ Household Financial Peaks } & \multicolumn{5}{|c|}{ Corporate Financial Peaks } \\
\hline & Count & Mean & SD & Min & Max & Count & Mean & SD & Min & Max \\
\hline Private debt-GDP ratio & 19 & 148.0 & 39.9 & 65.3 & 229.3 & 25 & 144.0 & 49.6 & 63.1 & 230.7 \\
\hline Household debt-GDP ratio & 19 & 61.1 & 23.1 & 17.6 & 107.5 & 25 & 56.2 & 26.5 & 9.6 & 124.2 \\
\hline Corporate debt-GDP ratio & 19 & 87.8 & 26.8 & 45.3 & 140.2 & 23 & 92.1 & 26.9 & 42.1 & 143.6 \\
\hline Public debt-GDP ratio & 17 & 49.1 & 28.4 & 9.7 & 109.4 & 19 & 58.7 & 24.1 & 17.0 & 108.8 \\
\hline Depth of recession & 18 & -6.4 & 4.3 & -16.9 & -0.7 & 24 & -5.0 & 2.3 & -9.6 & -0.7 \\
\hline Duration of recession & 18 & 3.6 & 2.0 & 2.0 & 10.0 & 24 & 2.7 & 1.5 & 1.0 & 6.0 \\
\hline Trade openness & 19 & 0.61 & 0.33 & 0.19 & 1.5 & 25 & 0.58 & 0.29 & 0.18 & 1.41 \\
\hline Financial openness & 18 & 3.1 & 2.6 & 0.2 & 10.3 & 23 & 3.1 & 2.5 & 0.4 & 11.2 \\
\hline World growth & 19 & 1.1 & 0.6 & -0.9 & 2.2 & 25 & 1.0 & 0.8 & -0.9 & 2.6 \\
\hline $\begin{array}{l}\text { Housing price increase during } \\
\text { expansion }\end{array}$ & 17 & 0.10 & 0.04 & 0.02 & 0.2 & 21 & 0.08 & 0.06 & 0.00 & 0.24 \\
\hline $\begin{array}{l}\text { Stock price increase during } \\
\text { expansion }\end{array}$ & 19 & 0.12 & 0.07 & -0.09 & 0.3 & 25 & 0.09 & 0.10 & -0.15 & 0.29 \\
\hline
\end{tabular}

(b) Emerging market economies

\begin{tabular}{|c|c|c|c|c|c|c|c|c|c|c|}
\hline \multirow[t]{2}{*}{ Item } & \multicolumn{5}{|c|}{ Normal Peaks } & \multicolumn{5}{|c|}{ Financial Peaks } \\
\hline & Count & Mean & SD & Min & $\operatorname{Max}$ & Count & Mean & SD & Min & $\operatorname{Max}$ \\
\hline Private debt-GDP ratio & 38 & 70.9 & 46.7 & 12.3 & 180.1 & 35 & 96.5 & 52.3 & 28.6 & 234.6 \\
\hline Household debt-GDP ratio & 32 & 24.0 & 19.9 & 0.1 & 79.7 & 25 & 33.3 & 22.1 & 2.0 & 72.3 \\
\hline Corporate debt-GDP ratio & 32 & 46.9 & 28.1 & 13.0 & 109.0 & 25 & 67.0 & 35.8 & 27.5 & 175.5 \\
\hline Public debt-GDP ratio & 17 & 45.7 & 22.4 & 17.1 & 84.7 & 14 & 41.2 & 28.5 & 3.7 & 101.0 \\
\hline Depth of recession & 33 & -6.0 & 3.3 & -12.7 & -0.5 & 34 & -8.8 & 5.9 & -27.9 & -1.2 \\
\hline Duration of recession & 33 & 2.4 & 1.7 & 1.0 & 9.0 & 34 & 2.7 & 1.7 & 1.0 & 8.0 \\
\hline Trade openness & 38 & 1.06 & 0.96 & 0.23 & 3.99 & 35 & 1.21 & 1.12 & 0.15 & 4.22 \\
\hline Financial openness & 33 & 2.6 & 4.4 & 0.3 & 19.0 & 32 & 3.7 & 6.2 & 0.4 & 24.3 \\
\hline World growth & 38 & 1.1 & 0.8 & -0.9 & 2.9 & 35 & 1.4 & 0.7 & -0.9 & 2.9 \\
\hline $\begin{array}{l}\text { Housing price increase during } \\
\text { expansion }\end{array}$ & 14 & 0.07 & 0.10 & -0.05 & 0.31 & 9 & 0.12 & 0.08 & 0.00 & 0.23 \\
\hline \multirow[t]{3}{*}{$\begin{array}{l}\text { Stock price increase during } \\
\text { expansion }\end{array}$} & 20 & 0.13 & 0.15 & -0.20 & 0.38 & 17 & 0.10 & 0.16 & -0.10 & 0.40 \\
\hline & \multicolumn{5}{|c|}{ Household Financial Peaks } & \multicolumn{5}{|c|}{ Corporate Financial Peaks } \\
\hline & Count & Mean & SD & Min & Max & Count & Mean & SD & Min & Max \\
\hline Private debt-GDP ratio & 7 & 98.3 & 43.7 & 41.0 & 150.5 & 15 & 105.2 & 59.0 & 28.6 & 234.6 \\
\hline Household debt-GDP ratio & 7 & 43.7 & 24.1 & 11.3 & 68.9 & 15 & 30.7 & 20.5 & 2.0 & 72.3 \\
\hline Corporate debt-GDP ratio & 7 & 54.6 & 22.3 & 29.9 & 84.3 & 15 & 74.6 & 40.5 & 27.5 & 175.5 \\
\hline Public debt-GDP ratio & 6 & 48.4 & 29.7 & 17.6 & 101.0 & 6 & 35.6 & 26.5 & 7.4 & 68.3 \\
\hline Depth of recession & 6 & -5.5 & 3.5 & -12.2 & -1.9 & 15 & -6.5 & 4.0 & -15.5 & -1.2 \\
\hline Duration of recession & 6 & 3.0 & 2.1 & 1.0 & 7.0 & 15 & 2.5 & 1.6 & 1.0 & 6.0 \\
\hline Trade openness & 7 & 1.24 & 1.21 & 0.24 & 3.80 & 15 & 1.33 & 1.28 & 0.33 & 4.22 \\
\hline Financial openness & 5 & 4.0 & 6.6 & 0.8 & 15.8 & 14 & 5.0 & 8.0 & 0.5 & 24.3 \\
\hline World growth & 7 & 1.2 & 0.2 & 0.9 & 1.5 & 15 & 1.4 & 0.9 & -0.9 & 2.9 \\
\hline $\begin{array}{l}\text { Housing price increase during } \\
\text { expansion }\end{array}$ & 4 & 0.12 & 0.09 & 0.01 & 0.23 & 4 & 0.10 & 0.09 & 0.00 & 0.20 \\
\hline $\begin{array}{l}\text { Stock price increase during } \\
\text { expansion }\end{array}$ & 6 & 0.06 & 0.17 & -0.10 & 0.30 & 6 & 0.03 & 0.12 & -0.10 & 0.20 \\
\hline
\end{tabular}

$\mathrm{GDP}=$ gross domestic product, $\mathrm{SD}=$ standard deviation

Notes: Summary statistics of emerging market economies reported using only the values at normal, financial, and household financial, and corporate financial peaks. Appendix Table A1 lists the advanced and emerging market economies.

Source: Authors' calculations. 
While recessions are generally more severe in EMEs, panels (a) and (b) show the depth of recessions is deeper after financial peaks than after normal peaks. ${ }^{12}$ Furthermore, the difference in the depth of recessions is larger in EMEs. Panel (a) shows that recessions are deeper after financial peaks driven by household debt than those driven by corporate debt. This is consistent with the findings of Mian, Sufi, and Verner (2017) that household debt accumulation entails more volatile business cycles. This is not true in EMEs, however. Panel (b) shows that recessions after financial peaks driven by household debt are not as severe as recessions after financial peaks driven by corporate debt. In general, the duration of recessions, defined as the period from a peak to the next trough, is longer after financial peaks than after normal peaks, although the difference is not sizable. There is no noticeable difference in trade openness across the different peaks, but financial openness is generally larger at financial peaks. The data on trade openness is from the World Development Indicators, with trade openness calculated as the sum of exports and imports divided by GDP. Financial openness is defined as the sum of external total assets and liabilities divided by GDP, and collected from the Lane and Milesi-Ferretti dataset. In AEs and EMEs, housing and stock prices rise faster before financial peaks, particularly if the peaks are driven by household debt accumulations.

While Table 3 is suggestive, the summary statistics do not control for observable and unobservable country-specific variables. For a more systematic analysis, we estimate the following equation:

$$
D R_{i \tau}^{j}=b_{0}^{j}+b_{N}^{j} \text { Peak }^{N}+b_{F}^{j} \text { Peak }^{F}+X_{i \tau} \cdot b^{j}+f_{i}^{j}+\epsilon_{i \tau}^{j},
$$

where $D R_{i \tau}^{j}$ is depth of recession of country $i$ at a peak which occurred at time $\tau$, in terms of

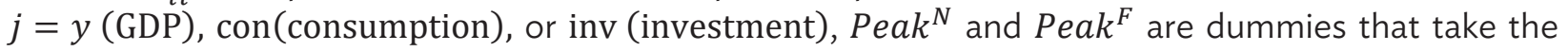
value of 1 if the corresponding peak is normal and financial, respectively, $X_{i \tau}$ is a vector of control variables for country $i$ at $\tau, f_{i}^{j}$ is country fixed effects for $j$ variable, and $\epsilon_{i \tau}^{j}$ is an error term. Since at time $\tau$, either Peak ${ }^{N}$ or Peak ${ }^{F}$ is equal to 1, we do not include a constant term.

\section{EMPIRICAL RESULTS}

This section discusses the empirical results. Table 4 shows the regression results for equation (1) for output (panel [a]), consumption (panel [b]), and investment (panel [c]) in AEs. Panel (a) shows that the dependent variable is the depth of output recession, defined as the average percentage change in GDP per capita from a peak to the next trough. We include only Peak ${ }^{N}$ and Peak ${ }^{F}$ as explanatory variables in column 1 of the table. We add trade openness, financial openness, and world output growth in column 2; add housing and stock price growth before the peak in column 3; and add all the variables in column 4 . In all columns, we do not include the constant term as a regressor. ${ }^{13}$ The control variables are identical to those in Claessens, Kose, and Terrones (2012). ${ }^{14}$ World output growth is defined as the 2-year average of world GDP growth after the peak. House and stock price growth is defined as the annual percentage change in housing and stock price indices from the previous trough

12 The summary statistics in Table 3 do not control country-specific variables. In Tables 4-8, we control unobserved country fixed effects by using country dummies as explanatory variables.

13 We do not include a constant as a regressor in the tables since otherwise there is a perfect multicollinearity with dummy variables. The estimated coefficients of peak dummy variables then represent the actual depth of recessions.

14 The main difference between this paper and Claessens, Kose, and Terrones (2012) is that they consider house and equity price busts as well as credit crunch. We focus, however, on financial peaks that are solely dependent on the speed of private debt accumulation. They also identify different business cycles of credit and define credit crunch recessions if output recessions coincide with credit downturns. 
to the peak. ${ }^{15}$ In panel (a), the depth of recessions in output is larger after financial peaks than after normal peaks. The annual difference is 1.0-1.6 percentage points depending on the specifications, and the $p$-values indicate it is statistically significant at the $1 \%$ level in columns $1-3$ and at the $10 \%$ level in column 4. The coefficients of trade openness and world output growth are positive, indicating that external demand can mitigate the severity of recessions, as suggested by Claessens, Kose, and Terrones (2012). Financial openness, however, is not statistically significant. House and stock price growth before peaks deepen the severity of recessions, but only the former is statistically significant in some specifications.

Table 4, panel (b), shows that the dependent variable is the depth of recession in consumption, defined the same way as output. Interestingly, we find no evidence that a consumption recession is deeper after financial peaks than after normal peaks. The results suggest there are more instruments (private and public) that can be used to support consumption during recessions even after financial peaks. The coefficients of trade openness and world output growth are positive, indicating that external demand can mitigate consumption recessions. Interestingly, stock price growth, but not house price growth, aggravates consumption recessions with statistical significance.

Table 4, panel (c), shows the regression results for the depth of recessions in investment. The difference of the depth between normal and financial peaks is 4.9 percentage points annually with a $p$-value equal to .06 if other control variables are not included. If they are included, the difference is not statistically significant. While more trade openness mitigates investment recessions, more financial openness aggravates investment recessions with statistical significance at the $1 \%$ level. ${ }^{16}$ There is some evidence that house price growth before a peak deepens investment recessions, but stock price growth is not related to the depth of investment recessions. We get qualitatively similar results when we repeat the exercise in Table 4 using stricter cutoff points of the top and bottom quartiles to distinguish between normal versus financial recessions, as explained earlier. ${ }^{17}$

15 Recessions with a house or equity price bust but not a credit crunch are deeper with statistical significance in Claessens, Kose, and Terrones (2012). We find, however, stronger evidence that financial peaks lead to deeper recessions.

16 While Claessens Kose, and Terrones (2012) find that financial openness has a significant and positive association with the depth of output recessions, we find the adversary impact of financial openness for investment only.

17 The results based on quartile cutoffs are available from the authors. 
Table 4: Depth of Recessions in Advanced Economies after Normal versus Financial Peaks

(a) Output

\begin{tabular}{lcccc}
\hline & \multicolumn{3}{c}{ Depth of Recession } \\
\cline { 2 - 4 } Variables & $(1)$ & $(2)$ & $(3)$ & $(4)$ \\
\hline Normal peak & $-4.6^{* *}$ & $-7.2^{* *}$ & $-4.2^{* *}$ & $-6.4^{* *}$ \\
$\left(\Delta d_{\text {priv }}<\right.$ median $\left.\left(\Delta d_{\text {priv }}\right)\right)$ & {$[1.1]$} & {$[1.4]$} & {$[1.0]$} & {$[1.3]$} \\
Financial peak & $-6.2^{* *}$ & $-8.7^{* *}$ & $-5.5^{* *}$ & $-7.4^{* *}$ \\
$\left(\Delta d_{\text {priv }}>\right.$ median $\left.\left(\Delta d_{\text {priv }}\right)\right)$ & {$[1.1]$} & {$[1.4]$} & {$[1.0]$} & {$[1.3]$} \\
Trade openness (at the peak) & & $5.1^{*}$ & & $4.8^{*}$ \\
& & {$[2.5]$} & & {$[2.4]$} \\
Financial openness (at the peak) & -0.11 & & $-0.19+$ \\
& & {$[0.13]$} & & {$[0.12]$} \\
World output growth & & $1.4^{*}$ & & $1.1^{* *}$ \\
$\quad(2$-year average following the peak) & & $0.56]$ & & {$[0.4]$} \\
House price growth & & $-9.6+$ & -6.1 \\
$\quad$ annual, during expansion before the peak) & & & {$[5.0]$} & {$[4.9]$} \\
Stock price growth & & -1.3 & -2.9 \\
$\quad$ (annual, during expansion before the peak) & & & {$[2.1]$} & {$[2.4]$} \\
\hline $\mathrm{R}^{2}$ & 0.82 & 0.86 & 0.86 & 0.88 \\
Observations, normal peaks & 63 & 49 & 54 & 43 \\
Observations, financial peaks & 66 & 60 & 55 & 52 \\
-value (norm vs fin) & 0.00 & 0.01 & 0.01 & 0.10 \\
\hline
\end{tabular}

(b) Consumption

\begin{tabular}{lcccc}
\hline & \multicolumn{3}{c}{ Depth of Recession } \\
\cline { 2 - 5 } Variables & $(1)$ & $(2)$ & $(3)$ & $(4)$ \\
\hline Normal peak & $-3.5^{* *}$ & $-7.3^{* *}$ & $-2.9^{* *}$ & $-7.5^{* *}$ \\
$\quad\left(\Delta d_{\text {priv }}<\right.$ median $\left.\left(\Delta d_{\text {priv }}\right)\right)$ & {$[0.8]$} & {$[1.5]$} & {$[0.8]$} & {$[1.7]$} \\
Financial peak & $-3.4^{* *}$ & $-6.7^{* *}$ & $-2.5^{* *}$ & $-6.6^{* *}$ \\
$\quad\left(\Delta d_{\text {priv }}>\right.$ median $\left.\left(\Delta d_{\text {priv }}\right)\right)$ & {$[0.76]$} & {$[1.22]$} & {$[0.90]$} & {$[1.56]$} \\
Trade openness (at the peak) & & 5.4 & & $9.2^{*}$ \\
& & {$[4.2]$} & & {$[4.5]$} \\
Financial openness (at the peak) & 0.06 & & -0.05 \\
& & {$[0.16]$} & & {$[0.17]$} \\
World output growth & & $1.7^{*}$ & & $1.3^{*}$ \\
$\quad(2$-year average following the peak) & & $0.66]$ & & {$[0.53]$} \\
House price growth & & -5.2 & 8.4 \\
$\quad$ annual, during expansion before the peak) & & & {$[7.0]$} & {$[7.3]$} \\
Stock price growth & & $-5.9^{*}$ & $-8.8^{*}$ \\
$\quad$ (annual, during expansion before the peak) & & & {$[2.83]$} & {$[3.4]$} \\
\hline $\mathrm{R}^{2}$ & 0.58 & 0.63 & 0.64 & 0.70 \\
Observations, normal peaks & 63 & 49 & 54 & 43 \\
Observations, financial peaks & 66 & 60 & 55 & 52 \\
p-value (norm vs fin) & 0.94 & 0.46 & 0.62 & 0.29 \\
\hline
\end{tabular}




\begin{tabular}{lcccc}
\hline & \multicolumn{3}{c}{ Depth of Recession } \\
\cline { 2 - 5 } Variables & $(1)$ & $(2)$ & $(3)$ & $(4)$ \\
\hline Normal peak & $-14 .^{* *}$ & $-23.9^{* *}$ & $-13.6^{* *}$ & $-20.7^{* *}$ \\
$\left(\Delta d_{\text {priv }}<\right.$ median $\left.\left(\Delta d_{\text {priv }}\right)\right)$ & {$[3.8]$} & {$[5.86]$} & {$[3.3]$} & {$[5.4]$} \\
Financial peak & $-19.0^{* *}$ & $-26.8^{* *}$ & $-15.5^{* *}$ & $-20.4^{* *}$ \\
$\left(\Delta d_{\text {priv }}>\right.$ median $\left.\left(\Delta d_{\text {priv }}\right)\right)$ & {$[4.0]$} & {$[5.5]$} & {$[3.7]$} & {$[5.0]$} \\
Trade openness (at the peak) & & $26.8^{*}$ & & $21.7^{*}$ \\
& & {$[12.0]$} & & {$[12.6]$} \\
Financial openness (at the peak) & $-0.96^{*}$ & & $-1.2^{* *}$ \\
& & {$[0.39]$} & & {$[0.37]$} \\
World output growth & 4.3 & & 3.2 \\
$\quad(2$-year average following the peak) & & {$[2.7]$} & & {$[2.4]$} \\
House price growth & & & $-46.4+$ & -43.5 \\
$\quad$ (annual, during expansion before the peak) & & & {$[23.8]$} & {$[28.3]$} \\
Stock price growth & & 6.8 & 1.6 \\
$\quad$ (annual, during expansion before the peak) & & & {$[9.3]$} & {$[11.7]$} \\
\hline $\mathrm{R}^{2}$ & 0.71 & 0.75 & 0.77 & 0.80 \\
Observations, normal peaks & 63 & 49 & 54 & 43 \\
Observations, financial peaks & 66 & 60 & 55 & 52 \\
$p$-value (norm vs fin) & 0.06 & 0.29 & 0.39 & 0.91 \\
\hline
\end{tabular}

Notes:

1. The dependent variable is the depth of recessions in output defined by the average percentage change in per capita gross domestic product (GDP) from a peak to the next trough. A constant term is not included as a regressor.

2. The sample of countries includes only the advanced economies listed in Appendix Table A1.

3. Normal and financial peaks are dummy variables that take the value of 1 if the peak is in normal and financial recessions, and zero otherwise. If the accumulation speed of private debts is higher than the sample median, the corresponding peak is defined as a financial peak and otherwise as a normal peak.

4. Trade openness is defined as the sum of exports and imports divided by GDP. Financial openness is defined as the sum of external total assets and liabilities divided by GDP.

5. The reported $p$-values are the test for equality of coefficients of normal versus financial peaks.

6. Numbers in brackets are robust standard errors.

7. **, *, and + denote significance levels of $1 \%, 5 \%$, and $10 \%$, respectively.

Source: Authors' calculations.

In Table 5, we report the regression results when the country sample is broadened to include EMEs. In the table's panel (a), the difference in the depth of output recessions is $1.2 \%-1.9 \%$ percentage points annually, somewhat larger than in Table 4, panel (a), with even greater statistical significance. We find that trade openness and world growth mitigate recessions. The evidence indicates that faster growth of house and stock prices before peaks deepens recessions, but the coefficients are not statistically significant. In Table 5, panel (b), we find stronger evidence that consumption recessions are deeper after financial peaks than after normal peaks. The coefficient of a financial peak is always larger in absolute value than that of a normal peak, and the difference is statistically significant at the $5 \%$ level in columns 1 and 2 . Depending on the specifications, the difference is $0.5 \%-1.5 \%$ percentage points annually. The results suggest there are fewer instruments in EMEs to mitigate consumption recessions than in AEs, particularly after financial peaks. We also find stronger evidence that investment recessions are more severe after financial peaks in panel (c). The difference of the coefficients of normal versus financial peaks is $2.4-8.8$ percentage points annually, and statistically significant at the $1 \%$ level in columns 1 and 2 . We find that trade openness mitigates investment 
recessions, but financial openness aggravates them. When we repeat the exercise for stricter quartile cutoffs, the results are also qualitatively similar. ${ }^{18}$

\section{Table 5: Depth of Recessions in Advanced and Emerging Market Economies after Normal versus Financial Peaks}

\section{(a) Output}

\begin{tabular}{lcccc}
\hline & \multicolumn{4}{c}{ Depth of Recession } \\
\cline { 2 - 5 } Variables & $(1)$ & $(2)$ & $(3)$ & $(4)$ \\
\hline Normal peak & $-4.5^{* *}$ & $-5.4^{* *}$ & $-4.3^{* *}$ & $-6.0^{* *}$ \\
$\quad\left(\Delta d_{\text {priv }}<\right.$ median $\left.\left(\Delta d_{\text {priv }}\right)\right)$ & {$[1.1]$} & {$[1.6]$} & {$[1.0]$} & {$[1.3]$} \\
Financial peak & $-6.4^{* *}$ & $-7.5^{* *}$ & $-5.6^{* *}$ & $-7.2^{* *}$ \\
$\quad\left(\Delta d_{\text {priv }}>\right.$ median $\left.\left(\Delta d_{\text {priv }}\right)\right)$ & {$[1.1]$} & {$[1.5]$} & {$[1.1]$} & {$[1.3]$} \\
Trade openness (at the peak) & & $3.2^{*}$ & & $3.4^{*}$ \\
& & {$[1.3]$} & & {$[1.3]$} \\
Financial openness (at the peak) & -0.14 & & -0.15 \\
& & {$[0.10]$} & & {$[0.10]$} \\
World output growth & & 0.47 & & $1.0^{*}$ \\
$\quad(2-$ year average following the peak) & & {$[0.48]$} & & {$[0.40]$} \\
House price growth & & -7.5 & -5.7 \\
$\quad$ (annual, during expansion before the peak) & & & {$[4.9]$} & {$[4.7]$} \\
Stock price growth & & -1.4 & -1.8 \\
$\quad$ (annual, during expansion before the peak) & & & {$[2.2]$} & {$[2.5]$} \\
\hline $\mathrm{R}^{2}$ & 0.82 & 0.84 & 0.84 & 0.87 \\
Observations, normal peaks & 96 & 81 & 65 & 54 \\
Observations, financial peaks & 100 & 92 & 63 & 59 \\
$p$-value (norm vs fin) & 0.00 & 0.00 & 0.02 & 0.07 \\
\hline
\end{tabular}

\section{(b) Consumption}

\begin{tabular}{|c|c|c|c|c|}
\hline \multirow[b]{2}{*}{ Variables } & \multicolumn{4}{|c|}{ Depth of Recession } \\
\hline & (1) & (2) & (3) & (4) \\
\hline \multirow{2}{*}{$\begin{array}{l}\text { Normal peak } \\
\qquad\left(\Delta d_{\text {priv }}<\text { median }\left(\Delta d_{\text {priv }}\right)\right)\end{array}$} & $-2.7^{* *}$ & $-3.1+$ & $-2.8^{* *}$ & $-4.8^{* *}$ \\
\hline & {$[0.9]$} & [1.6] & {$[0.87]$} & {$[1.3]$} \\
\hline \multirow{4}{*}{$\begin{array}{l}\text { Financial peak } \\
\quad\left(\Delta d_{\text {priv }}>\text { median }\left(\Delta d_{\text {priv }}\right)\right) \\
\text { Trade openness (at the peak) }\end{array}$} & $-4.2^{* *}$ & $-4.8^{* *}$ & $-3.3^{* *}$ & $-5.2^{* *}$ \\
\hline & {$[0.9]$} & {$[1.4]$} & {$[1.1]$} & {$[1.4]$} \\
\hline & & 0.04 & & -0.37 \\
\hline & & {$[2.6]$} & & {$[2.2]$} \\
\hline \multirow[t]{2}{*}{ Financial openness (at the peak) } & & 0.17 & & 0.19 \\
\hline & & {$[0.16]$} & & {$[0.14]$} \\
\hline World output growth & & -0.02 & & $1.1^{*}$ \\
\hline (2-year average following the peak) & & {$[0.71]$} & & [0.55] \\
\hline House price growth & & & -4.6 & -0.82 \\
\hline (annual, during expansion before the peak) & & & {$[7.2]$} & {$[8.4]$} \\
\hline Stock price growth & & & -1.9 & -1.8 \\
\hline (annual, during expansion before the peak) & & & {$[3.2]$} & {$[4.2]$} \\
\hline
\end{tabular}

18 The results based on quartile cutoffs are available from the authors. 
Table 5 continued

\begin{tabular}{lcccc}
\hline & \multicolumn{4}{c}{ Depth of Recession } \\
\cline { 2 - 5 } Variables & $(1)$ & $(2)$ & $(3)$ & $(4)$ \\
\hline $\mathrm{R}^{2}$ & 0.61 & 0.61 & 0.60 & 0.63 \\
Observations, normal peaks & 96 & 81 & 65 & 54 \\
Observations, financial peaks & 100 & 92 & 63 & 59 \\
$p$-value (norm vs fin) & 0.05 & 0.05 & 0.48 & 0.65 \\
\hline
\end{tabular}

(c) Investment

\begin{tabular}{lcccc}
\hline & \multicolumn{3}{c}{ Depth of Recession } \\
\cline { 2 - 5 } Variables & $(1)$ & $(2)$ & $(3)$ & $(4)$ \\
\hline Normal peak & $-12.1^{* *}$ & $-15.4^{*}$ & $-14.2^{* *}$ & $-19.8^{* *}$ \\
$\left(\Delta d_{\text {priv }}<\right.$ median $\left.\left(\Delta d_{\text {priv }}\right)\right)$ & {$[4.5]$} & {$[6.1]$} & {$[3.5]$} & {$[4.8]$} \\
Financial peak & $-20.9^{* *}$ & $-23.8^{* *}$ & $-17.8^{* *}$ & $-22.2^{* *}$ \\
$\left(\Delta d_{\text {priv }}>\right.$ median $\left.\left(\Delta d_{\text {priv }}\right)\right)$ & {$[4.6]$} & {$[5.9]$} & {$[4.2]$} & {$[5.1]$} \\
Trade openness (at the peak) & & $16.9^{*}$ & & $14.3^{* *}$ \\
& & {$[7.8]$} & & {$[4.7]$} \\
Financial openness (at the peak) & -0.72 & & $-0.75^{*}$ \\
& & {$[0.53]$} & & {$[0.29]$} \\
World output growth & & 1.1 & & 2.8 \\
$\quad(2$-year average following the peak) & & {$[2.2]$} & & {$[2.3]$} \\
House price growth & & -24.0 & -22.1 \\
$\quad$ (annual, during expansion before the peak) & & & {$[23.3]$} & {$[25.6]$} \\
Stock price growth & & 9.8 & 10.4 \\
$\quad$ (annual, during expansion before the peak) & & & {$[10.2]$} & {$[13.2]$} \\
\hline $\mathrm{R}^{2}$ & 0.70 & 0.73 & 0.74 & 0.76 \\
Observations, normal peaks & 96 & 81 & 65 & 54 \\
Observations, financial peaks & 100 & 92 & 63 & 59 \\
$p$-value (norm vs fin) & 0.00 & 0.00 & 0.14 & 0.41 \\
\hline
\end{tabular}

Notes:

1. The dependent variable is the depth of recessions in output defined by the average percentage change in gross domestic product (GDP) per capita from a peak to the next trough. A constant term is not included as a regressor.

2. The sample comprises both the advanced and emerging market economies listed in Appendix Table A1.

3. Normal and financial peaks are dummy variables that take the value of 1 if the peak is normal and financial, respectively, and zero otherwise. If the accumulation speed of private debts is higher than the sample median, the corresponding peak is defined as a financial peak and otherwise as a normal peak.

4. Trade openness is defined as the sum of exports and imports divided by GDP. Financial openness is defined as the sum of external total assets and liabilities divided by GDP.

5. The reported $p$-values are the test for equality of coefficients of normal versus financial peaks.

6. Numbers in brackets are robust standard errors.

7. ${ }^{* *}$ and ${ }^{*}$ denote significance levels of $1 \%$ and $5 \%$, respectively.

Source: Authors' calculations.

As noted earlier, most studies define a peak as a financial peak if a financial crisis occurred. In contrast to this, we define financial peaks on the basis of the accumulation speed of debt buildups before peaks. Since our approach ignores the dates of financial crises, it is likely to include financial peaks that do not coincide with financial crises. To compare our analysis with other studies, we define two types of financial peaks. The first is a financial peak that coincides with a financial crisis, which we call a crisis financial peak. The second is a financial peak that does not coincide with a financial crisis, which we call a noncrisis financial peak. When we include both types of financial peaks as regressors, most of our earlier results are preserved for all economies in the sample. Furthermore, the effects of both types of financial 
peaks on recessions are qualitatively similar. For example, both crisis and noncrisis financial output recessions are deeper than normal recessions, and the differences are statistically significant. ${ }^{19}$

In Tables 6 and 7, we further distinguish between house and corporate financial peaks by comparing each debt's accumulation speed in the preceding boom. We report the regression results for AEs (Table 6) and for all countries (Table 7). In Table 7, panel (a), we find that recessions after household financial peaks, while not statistically significant, are severer than after corporate financial peaks. Compared with normal recessions, household financial recessions are significantly deeper in columns 1-3, at least at the $10 \%$ level, while corporate financial recessions are significantly deeper only in columns 1 and 3. These results are generally consistent with Mian, Sufi, and Verner (2017), which find that household debt accumulation leads to more volatile boom-bust cycles in AEs. In Table 6, panel (b), consumption recessions, while not statistically significant, are deeper after household financial peaks than after corporate financial peaks. Even compared to the normal peak, the difference is much smaller than in panel (a). Relative to normal recessions, we find that consumption recessions are deeper after a household financial peak and shallower after a normal peak. The results in panel (c) for investment recessions are similar to those for consumption recessions. While investment recessions are severer after household and corporate financial peaks than after normal peaks, the difference is not statistically significant.

\section{Table 6: Depth of Recessions in Advanced Economies after Household versus Corporate Financial Peaks}

(a) Output

\begin{tabular}{|c|c|c|c|c|}
\hline \multirow[b]{2}{*}{ Variables } & \multicolumn{4}{|c|}{ Depth of Recession } \\
\hline & (1) & (2) & (3) & (4) \\
\hline $\begin{array}{l}\text { Normal peak } \\
\qquad\left(\Delta d_{\text {priv }}<\text { median }\left(\Delta d_{\text {priv }}\right)\right)\end{array}$ & $\begin{array}{l}-4.7^{* *} \\
{[1.1]}\end{array}$ & $\begin{array}{l}-7.0^{* *} \\
{[1.4]}\end{array}$ & $\begin{array}{l}-4.3^{* *} \\
{[1.0]}\end{array}$ & $\begin{array}{l}-6.5^{* *} \\
{[1.3]}\end{array}$ \\
\hline Household financial peak & $-6.4^{* *}$ & $-9.1^{* *}$ & $-5.7^{* *}$ & $-7.9^{* *}$ \\
\hline$\left(\Delta d_{\text {corp }}<\Delta d_{h h d}\right)$ & {$[1.1]$} & {$[1.5]$} & {$[1.1]$} & {$[1.5]$} \\
\hline Corporate financial peak & $-5.7^{* *}$ & $-7.8^{* *}$ & $-5.3^{* *}$ & $-7.0^{* *}$ \\
\hline$\left(\Delta d_{\text {corp }}>\Delta d_{h h d}\right)$ & {$[1.2]$} & {$[1.5]$} & {$[1.1]$} & {$[1.4]$} \\
\hline Trade openness (at the peak) & & $\begin{array}{c}2.6 \\
{[3.0]}\end{array}$ & & $\begin{array}{c}3.3 \\
{[2.9]}\end{array}$ \\
\hline Financial openness (at the peak) & & $\begin{array}{c}0.19 \\
{[0.18]}\end{array}$ & & $\begin{array}{l}-0.01 \\
{[0.17]}\end{array}$ \\
\hline $\begin{array}{l}\text { World output growth } \\
\text { (2-year average following the peak) }\end{array}$ & & $\begin{array}{l}1.5^{* *} \\
{[0.5]}\end{array}$ & & $\begin{array}{l}1.1^{* *} \\
{[0.36]}\end{array}$ \\
\hline $\begin{array}{l}\text { House price growth } \\
\text { (annual, during expansion before the peak) }\end{array}$ & & & $\begin{array}{l}-8.7 \\
{[5.6]}\end{array}$ & $\begin{array}{l}-2.6 \\
{[5.0]}\end{array}$ \\
\hline $\begin{array}{l}\text { Stock price growth } \\
\text { (annual, during expansion before the peak) }\end{array}$ & & & $\begin{array}{l}-0.4 \\
{[2.4]}\end{array}$ & $\begin{array}{l}-2.1 \\
{[2.7]}\end{array}$ \\
\hline $\mathrm{R}^{2}$ & 0.81 & 0.86 & 0.85 & 0.88 \\
\hline $\begin{array}{l}\text { Observations, normal peaks } \\
\text { Observations, household fin peaks }\end{array}$ & $\begin{array}{l}63 \\
18\end{array}$ & $\begin{array}{l}49 \\
18\end{array}$ & $\begin{array}{l}54 \\
17\end{array}$ & $\begin{array}{l}43 \\
17\end{array}$ \\
\hline Observations, corporate fin peaks & 24 & 23 & 21 & 21 \\
\hline$p$-value (norm vs HHD fin) & 0.10 & 0.04 & 0.10 & 0.18 \\
\hline$p$-value (norm vs corp fin) & 0.10 & 0.25 & 0.09 & 0.50 \\
\hline$p$-value (HHD fin vs corp fin) & 0.50 & 0.22 & 0.65 & 0.31 \\
\hline
\end{tabular}

continued on next page

19 The results we get when we use both crisis and noncrisis financial peaks as regressors are available from authors. 


\section{(b) Consumption}

\begin{tabular}{|c|c|c|c|c|}
\hline \multirow[b]{2}{*}{ Variables } & \multicolumn{4}{|c|}{ Depth of Recession } \\
\hline & (1) & (2) & (3) & (4) \\
\hline Normal peak & $-3.2^{* *}$ & $-7.9^{* *}$ & $-2.9^{* *}$ & $-7.9^{* *}$ \\
\hline$\left(\Delta d_{\text {priv }}<\operatorname{median}\left(\Delta d_{\text {priv }}\right)\right)$ & {$[0.9]$} & {$[1.2]$} & {$[0.9]$} & [1.3] \\
\hline Household financial peak & $-4.5^{* *}$ & $-9.6^{* *}$ & $-3.1^{* *}$ & $-8.7^{* *}$ \\
\hline$\left(\Delta d_{c o r p}<\Delta d_{h h d}\right)$ & {$[1.0]$} & {$[1.5]$} & {$[1.1]$} & {$[1.6]$} \\
\hline Corporate financial peak & $-2.0^{*}$ & $-6.6^{* *}$ & -1.2 & $-6.2^{* *}$ \\
\hline$\left(\Delta d_{\text {corp }}>\Delta d_{h h d}\right)$ & {$[0.9]$} & {$[1.1]$} & {$[1.0]$} & {$[1.4]$} \\
\hline \multirow[t]{2}{*}{ Trade openness (at the peak) } & & $7.8+$ & & $10.1^{* *}$ \\
\hline & & {$[4.2]$} & & {$[3.7]$} \\
\hline \multirow[t]{2}{*}{ Financial openness (at the peak) } & & 0.46 & & 0.29 \\
\hline & & [0.29] & & [0.28] \\
\hline World output growth & & $2.1^{* *}$ & & $1.4^{* *}$ \\
\hline (2-year average following the peak) & & {$[0.68]$} & & [0.49] \\
\hline House price growth & & & -5.3 & 12.5 \\
\hline (annual, during expansion before the peak) & & & {$[8.4]$} & [7.5] \\
\hline Stock price growth & & & $-5.8+$ & $-7.9+$ \\
\hline (annual, during expansion before the peak) & & & {$[3.2]$} & {$[4.2]$} \\
\hline$R^{2}$ & 0.60 & 0.73 & 0.6 & 0.8 \\
\hline Observations, normal peaks & 63 & 49 & 54 & 43 \\
\hline Observations, household fin peaks & 18 & 18 & 17 & 17 \\
\hline Observations, corporate fin peaks & 24 & 23 & 21 & 21 \\
\hline$p$-value (norm vs HHD fin) & 0.31 & 0.16 & 0.83 & 0.58 \\
\hline$p$-value (norm vs corp fin) & 0.10 & 0.15 & 0.04 & 0.10 \\
\hline$p$-value (HHD fin vs corp fin) & 0.04 & 0.01 & 0.11 & 0.03 \\
\hline
\end{tabular}

\section{(c) Investment}

\begin{tabular}{|c|c|c|c|c|}
\hline \multirow[b]{2}{*}{ Variables } & \multicolumn{4}{|c|}{ Depth of Recession } \\
\hline & $(1)$ & (2) & (3) & (4) \\
\hline $\begin{array}{l}\text { Normal peak } \\
\qquad\left(\Delta d_{\text {priv }}<\text { median }\left(\Delta d_{\text {priv }}\right)\right)\end{array}$ & $\begin{array}{l}-14.6^{* *} \\
{[3.8]}\end{array}$ & $\begin{array}{l}-21.9^{* *} \\
{[5.3]}\end{array}$ & $\begin{array}{c}-13.6^{* *} \\
{[3.5]}\end{array}$ & $\begin{array}{l}-19.3^{* *} \\
{[5.4]}\end{array}$ \\
\hline $\begin{array}{l}\text { Household financial peak } \\
\qquad\left(\Delta d_{\text {corp }}<\Delta d_{h h d}\right)\end{array}$ & $\begin{array}{l}-18.5^{* *} \\
{[4.6]}\end{array}$ & $\begin{array}{l}-25.6^{* *} \\
{[6.4]}\end{array}$ & $\begin{array}{l}-15.6^{* *} \\
{[4.5]}\end{array}$ & $\begin{array}{l}-19.0^{* *} \\
{[6.7]}\end{array}$ \\
\hline $\begin{array}{l}\text { Corporate financial peak } \\
\qquad\left(\Delta d_{\text {corp }}>\Delta d_{h h d}\right)\end{array}$ & $\begin{array}{c}-18.4^{* *} \\
{[4.3]}\end{array}$ & $\begin{array}{l}-24.2^{* *} \\
{[5.5]}\end{array}$ & $\begin{array}{c}-16.5^{* *} \\
{[4.3]}\end{array}$ & $\begin{array}{l}-20.0^{* *} \\
{[5.7]}\end{array}$ \\
\hline Trade openness (at the peak) & & $\begin{array}{l}24.0 \\
{[15.1]}\end{array}$ & & $\begin{array}{l}29.9+ \\
{[15.7]}\end{array}$ \\
\hline Financial openness (at the peak) & & $\begin{array}{l}-0.75 \\
{[0.77]}\end{array}$ & & $\begin{array}{c}-1.6+ \\
{[0.86]}\end{array}$ \\
\hline $\begin{array}{l}\text { World output growth } \\
\text { (2-year average following the peak) }\end{array}$ & & $\begin{array}{l}2.9 \\
{[2.3]}\end{array}$ & & $\begin{array}{l}0.50 \\
{[2.0]}\end{array}$ \\
\hline $\begin{array}{l}\text { House price growth } \\
\text { (annual, during expansion before the peak) }\end{array}$ & & & $\begin{array}{l}-45.0^{*} \\
{[20.6]}\end{array}$ & $\begin{array}{l}-33.9 \\
{[22.7]}\end{array}$ \\
\hline $\begin{array}{l}\text { Stock price growth } \\
\text { (annual, during expansion before the peak) }\end{array}$ & & & $\begin{array}{c}8.1 \\
{[9.0]}\end{array}$ & $\begin{array}{c}-1.2 \\
{[11.4]}\end{array}$ \\
\hline $\begin{array}{l}\mathrm{R}^{2} \\
\text { Observations, normal peaks }\end{array}$ & $\begin{array}{c}0.71 \\
63\end{array}$ & $\begin{array}{c}0.76 \\
49\end{array}$ & $\begin{array}{l}0.8 \\
54\end{array}$ & $\begin{array}{l}0.8 \\
43\end{array}$ \\
\hline Observations, household fin peaks & 18 & 18 & 17 & 17 \\
\hline Observations, corporate fin peaks & 24 & 23 & 21 & 21 \\
\hline$p$-value (norm vs HHD fin) & 0.33 & 0.38 & 0.57 & 0.93 \\
\hline
\end{tabular}




\begin{tabular}{lcccc}
\hline & \multicolumn{4}{c}{ Depth of Recession } \\
\cline { 2 - 5 } Variables & $(1)$ & $(2)$ & (3) & (4) \\
\hline$p$-value (norm vs corp fin) & 0.17 & 0.47 & 0.28 & 0.83 \\
$p$-value (HHD fin vs corp fin) & 0.98 & 0.74 & 0.78 & 0.77 \\
\hline
\end{tabular}

HHD = household.

Notes:

1. The dependent variable is the depth of recessions in output defined by the average percentage change in gross domestic product (GDP) per capita from a peak to the next trough. A constant term is not included as a regressor.

2. The sample of countries includes only the advanced economies listed in Appendix Table A1.

3. Normal, household financial, and corporate financial peaks are dummy variables that take the value of 1 if the peak is normal, household financial, and corporate financial, respectively, and zero otherwise.

4. Trade openness is defined as the sum of exports and imports divided by GDP. Financial openness is defined as the sum of external total assets and liabilities divided by GDP.

5. The reported $p$-values, (norm vs HHD fin), (norm vs corp fin), and (HHD fin vs corp fin) are the test for equality of coefficients of normal versus household financial peaks, normal versus corporate financial peaks, and household versus corporate financial peaks, respectively.

6. Numbers in brackets are robust standard errors.

7. ${ }^{* *},{ }^{*}$, and + denote significance levels of $1 \%, 5 \%$, and $10 \%$, respectively.

Source: Authors' calculations.

Table 7 shows the same regression results for all economies. In panel (a), output recessions are severer after both household and corporate financial peaks than after normal peaks, but the difference is not generally statistically significant. In column 3, the output recessions after corporate financial peaks are deeper than after normal peaks at the 10\% significance level-and this is the only case where the hypothesis of no difference is rejected. Furthermore, we find that recessions driven by corporate debt buildups are equally severe or even more severe than those driven by household debt buildups. These results are consistent with Park, Shin, and Tian (2018) that emphasize the damaging effect of corporate debt-driven business cycles in EMEs.

Table 7, panel (b), shows the results for consumption recessions. Generally, we find that consumption recessions driven by both household and corporate debt buildups are severer than normal recessions, but the difference is not statistically significant. Panel (c) shows that investment drops more during recessions, driven by household and corporate debt buildups. In column 3 , the difference is statistically significant at the $10 \%$ level. Investment recessions are deeper after corporate financial peaks than after household financial peaks in columns 3 and 4. These results again suggest that recessions driven by corporate debt buildups can be as damaging as those driven by household debt buildups if EMEs are included in the sample. 


\section{Table 7: Depth of Recessions in Advanced and Emerging Market Economies after Household versus Corporate Financial Peaks}

(a) Output

\begin{tabular}{lcccc}
\hline & \multicolumn{3}{c}{ Depth of Recession } \\
\cline { 2 - 5 } Variables & $(1)$ & $(2)$ & $(3)$ & $(4)$ \\
\hline Normal peak & $-5.0^{* *}$ & $-6.6^{* *}$ & $-4.4^{* *}$ & $-6.1^{* *}$ \\
$\left.\quad \Delta d_{\text {corp }}>\Delta d_{\text {hhd }}\right)$ & {$[1.0]$} & {$[1.3]$} & {$[1.0]$} & {$[1.4]$} \\
Household financial peak & $-6.2^{* *}$ & $-8.1^{* *}$ & $-5.6^{* *}$ & $-7.3^{* *}$ \\
$\left.\quad \Delta d_{\text {corp }}<\Delta d_{\text {hhd }}\right)$ & {$[1.1]$} & {$[1.4]$} & {$[1.1]$} & {$[1.4]$} \\
Corporate financial peak & $-5.4^{* *}$ & $-7.3^{* *}$ & $-5.7^{* *}$ & $-7.3^{* *}$ \\
$\quad\left(\Delta d_{\text {corp }}>\Delta d_{\text {hhd }}\right.$ ) & {$[1.1]$} & {$[1.4]$} & {$[1.3]$} & {$[1.6]$} \\
Trade openness (at the peak) & & $4.4^{* *}$ & & $3.6^{*}$ \\
& & {$[1.5]$} & & {$[1.6]$} \\
Financial openness (at the peak) & -0.21 & & -0.09 \\
& & {$[0.16]$} & & {$[0.15]$} \\
World output growth & & $0.98^{*}$ & & $0.84+$ \\
$\quad(2$-year average following the peak) & & & & {$[0.42]$} \\
House price growth & & & $-6.46]$ & {$[5.9$} \\
$\quad$ (annual, during expansion before the peak) & & & $-0.2]$ & -0.5 \\
Stock price growth & & & {$[2.4]$} & {$[3.0]$} \\
$\quad$ (annual, during expansion before the peak) & & 0.85 & 0.84 & 0.87 \\
\hline$R^{2}$ & 0.82 & 81 & 65 & 54 \\
Observations, normal peaks & 96 & 23 & 20 & 19 \\
Observations, household fin peaks & 24 & 37 & 25 & 25 \\
Observations, corporate fin peaks & 39 & 0.11 & 0.14 & 0.19 \\
$p$-value (norm vs HHD fin) & 0.14 & 0.34 & 0.10 & 0.22 \\
$p$-value (norm vs corp fin) & 0.40 & 0.36 & 0.89 & 0.96 \\
$p$-value (HHD fin vs corp fin) & 0.39 & & \\
\hline
\end{tabular}

\begin{tabular}{|c|c|c|c|c|}
\hline \multirow[b]{2}{*}{ Variables } & \multicolumn{4}{|c|}{ Depth of Recession } \\
\hline & (1) & (2) & (3) & (4) \\
\hline $\begin{array}{l}\text { Normal peak } \\
\qquad\left(\Delta d_{\text {corp }}>\Delta d_{h h d}\right)\end{array}$ & $\begin{array}{l}-2.9^{* *} \\
{[0.9]}\end{array}$ & $\begin{array}{l}-4.2^{* *} \\
{[1.5]}\end{array}$ & $\begin{array}{l}-2.6^{* *} \\
{[0.9]}\end{array}$ & $\begin{array}{c}-4.7^{* *} \\
{[1.3]}\end{array}$ \\
\hline Household financial peak & $-4.5^{* *}$ & $\begin{array}{l}-6.1^{* *} \\
{[1.6\rceil}\end{array}$ & $\begin{array}{l}-3.9^{* *} \\
{[1.2\rceil}\end{array}$ & $\begin{array}{l}-6.2^{* *} \\
{[1.71}\end{array}$ \\
\hline $\begin{array}{l}\left(\Delta d_{\text {corp }}<\Delta d_{h h d}\right) \\
\text { Corporate financial peak }\end{array}$ & $\begin{array}{c}{[1.0]} \\
-2.9^{* *}\end{array}$ & $\begin{array}{c}{[1.6]} \\
-4.7^{* *}\end{array}$ & $\begin{array}{c}{[1.2]} \\
-2.6+\end{array}$ & $\begin{array}{l}{[1.7]} \\
-5.0^{*}\end{array}$ \\
\hline $\begin{array}{l}\quad\left(\Delta d_{\text {corp }}>\Delta d_{\text {hhd }}\right) \\
\text { Trade openness (at the peak) }\end{array}$ & {$[1.1]$} & $\begin{array}{c}{[1.4]} \\
-0.17 \\
{[2.96]}\end{array}$ & {$[1.4]$} & $\begin{array}{c}{[1.9]} \\
-0.60 \\
{[2.66]}\end{array}$ \\
\hline Financial openness (at the peak) & & $\begin{array}{l}0.44+ \\
{[0.25]}\end{array}$ & & $\begin{array}{c}0.45 \\
{[0.29]}\end{array}$ \\
\hline $\begin{array}{l}\text { World output growth } \\
\text { (2-year average following the peak) }\end{array}$ & & $\begin{array}{c}0.62 \\
{[0.79]}\end{array}$ & & $\begin{array}{c}1.1 \\
{[0.7]}\end{array}$ \\
\hline $\begin{array}{l}\text { House price growth } \\
\text { (annual, during expansion before the peak) }\end{array}$ & & & $\begin{array}{l}-6.3 \\
{[8.4]}\end{array}$ & $\begin{array}{c}-3.3 \\
{[10.6]}\end{array}$ \\
\hline $\begin{array}{l}\text { Stock price growth } \\
\text { (annual, during expansion before the peak) }\end{array}$ & & & $\begin{array}{l}-0.73 \\
{[3.6]}\end{array}$ & $\begin{array}{l}0.92 \\
{[5.4]}\end{array}$ \\
\hline
\end{tabular}




\begin{tabular}{lcccc}
\hline & \multicolumn{3}{c}{ Depth of Recession } \\
\cline { 2 - 5 } Variables & $(1)$ & $(2)$ & (3) & 0.6 \\
\hline $\mathrm{R}^{2}$ & 0.58 & 0.61 & 65 & 0.6 \\
Observations, normal peaks & 96 & 81 & 20 & 19 \\
Observations, household fin peaks & 24 & 23 & 37 & 25 \\
Observations, corporate fin peaks & 39 & 0.13 & 0.29 & 0.25 \\
$p$-value (norm vs HHD fin) & 0.17 & 0.67 & 0.99 & 0.83 \\
$p$-value (norm vs corp fin) & 0.97 & 0.29 & 0.32 & 0.41
\end{tabular}

\section{(c) Investment}

\begin{tabular}{|c|c|c|c|c|}
\hline \multirow[b]{2}{*}{ Variables } & \multicolumn{4}{|c|}{ Depth of Recession } \\
\hline & (1) & $(2)$ & (3) & (4) \\
\hline $\begin{array}{l}\text { Normal peak } \\
\qquad\left(\Delta d_{\text {corp }}>\Delta d_{h h d}\right)\end{array}$ & $\begin{array}{l}-14.4^{* *} \\
{[3.9]}\end{array}$ & $\begin{array}{l}-19.3^{* *} \\
{[5.3]}\end{array}$ & $\begin{array}{l}-14.4^{* *} \\
{[3.9]}\end{array}$ & $\begin{array}{l}-17.1^{* *} \\
{[5.3]}\end{array}$ \\
\hline $\begin{array}{l}\text { Household financial peak } \\
\qquad\left(\Delta d_{\text {corp }}<\Delta d_{h h d}\right)\end{array}$ & $\begin{array}{c}-18.9^{* *} \\
{[4.6]}\end{array}$ & $\begin{array}{l}-23.2^{* *} \\
{[5.9]}\end{array}$ & $\begin{array}{c}-17.2^{* *} \\
{[4.8]}\end{array}$ & $\begin{array}{c}-18.5^{* *} \\
{[6.2]}\end{array}$ \\
\hline $\begin{array}{l}\text { Corporate financial peak } \\
\qquad\left(\Delta d_{\text {corp }}>\Delta d_{h h d}\right)\end{array}$ & $\begin{array}{c}-18.0^{* *} \\
{[4.5]}\end{array}$ & $\begin{array}{l}-22.7^{* *} \\
{[5.4]}\end{array}$ & $\begin{array}{l}-20.0^{* *} \\
{[5.2]}\end{array}$ & $\begin{array}{l}-23.4^{* *} \\
{[6.6]}\end{array}$ \\
\hline Trade openness (at the peak) & & $\begin{array}{l}19.8^{*} \\
{[8.1]}\end{array}$ & & $\begin{array}{l}16.0^{*} \\
{[6.8]}\end{array}$ \\
\hline Financial openness (at the peak) & & $\begin{array}{c}-1.1 \\
{[0.87]}\end{array}$ & & $\begin{array}{l}-0.53 \\
{[0.69]}\end{array}$ \\
\hline $\begin{array}{l}\text { World output growth } \\
\text { (2-year average following the peak) }\end{array}$ & & $\begin{array}{l}1.9 \\
{[2.1]}\end{array}$ & & $\begin{array}{l}-0.13 \\
{[2.1]}\end{array}$ \\
\hline $\begin{array}{l}\text { House price growth } \\
\text { (annual, during expansion before the peak) }\end{array}$ & & & $\begin{array}{l}-20.6 \\
{[21.1]}\end{array}$ & $\begin{array}{l}-21.9 \\
{[21.2]}\end{array}$ \\
\hline $\begin{array}{l}\text { Stock price growth } \\
\text { (annual, during expansion before the peak) }\end{array}$ & & & $\begin{array}{c}10.5 \\
{[10.5]}\end{array}$ & $\begin{array}{l}12.6 \\
{[15.0]}\end{array}$ \\
\hline $\mathrm{R}^{2}$ & 0.70 & 0.73 & 0.7 & 0.8 \\
\hline Observations, normal peaks & 96 & 81 & 65 & 54 \\
\hline Observations, household fin peaks & 24 & 23 & 20 & 19 \\
\hline Observations, corporate fin peaks & 39 & 37 & 25 & 25 \\
\hline$p$-value (norm vs HHD fin) & 0.24 & 0.36 & 0.44 & 0.75 \\
\hline$p$-value (norm vs corp fin) & 0.22 & 0.32 & 0.10 & 0.18 \\
\hline$p$-value (HHD fin vs corp fin) & 0.83 & 0.91 & 0.48 & 0.28 \\
\hline
\end{tabular}

$\mathrm{HHD}=$ household.

Notes:

1. The dependent variable is the depth of recessions in output defined by the average percentage change in gross domestic product (GDP) per capita from a peak to the next trough. A constant term is not included as a regressor.

2. The sample comprises both the advanced and emerging market economies listed in Appendix Table A1.

3. Normal, household financial, and corporate financial peaks are dummy variables that take the value of 1 if the peak is normal, household financial, and corporate financial, respectively, and zero otherwise.

4. Trade openness is defined as the sum of exports and imports divided by GDP. Financial openness is defined as the sum of external total assets and liabilities divided by GDP.

5. The reported $p$-values, (norm vs HHD fin), (norm vs corp fin), and (HHD fin vs corp fin) are the test for equality of coefficients of normal versus household financial peaks, normal versus corporate financial peaks, and household versus corporate financial peaks, respectively.

6. Numbers in brackets are robust standard errors.

7. **, *, and + denote significance levels of $1 \%, 5 \%$, and $10 \%$, respectively.

Source: Authors' calculations. 
In Table 8, we consider policy effects that can potentially mitigate recessions. Romer and Romer (2017b) argue that macroeconomic policy plays an important role in explaining variation in macroeconomic performance after financial crises. They find that the public debt-GDP ratio greatly affects postcrisis performance. To examine whether the public debt-GDP ratio influences the depth of recessions after financial peaks, Table 8 , panel (a), shows the results for output recessions when we include interactions between normal (financial) peaks and both the linear and square terms of the public debt-GDP ratio. ${ }^{20}$ In columns 1 and 2 , we consider only AEs only. In column 1 , while interactions of the normal peak with the linear and square term of the public debt-GDP ratio are not statistically significant, interactions of the financial peak with the square term of the ratio are statistically significant at the $10 \%$ level. In column 2, when we distinguish between household and corporate financial peaks, the interaction terms of both with the square term of the public debt-GDP ratio are statistically significant at the $5 \%$ level. According to the estimated coefficients, the coefficient of the financial peak reaches its minimum when the ratio is $57.9 \%$. This means that increases in the public debt-GDP ratio from low initial levels may not deepen the severity of recessions since there is still room for countercyclical fiscal policy. But if the ratio is so high that it becomes difficult to conduct fiscal policy, recessions tend to be deeper, especially if they are driven by financial debt buildups.

Table 8: Depth of Recessions and Fiscal Policy Space

(a) Output

\begin{tabular}{|c|c|c|c|c|}
\hline \multirow[b]{3}{*}{ Variables } & \multicolumn{4}{|c|}{ Depth of Recession } \\
\hline & \multicolumn{2}{|c|}{ Advanced Economies } & \multicolumn{2}{|c|}{ Advanced and Emerging } \\
\hline & (1) & (2) & (3) & (4) \\
\hline $\begin{array}{l}\text { Normal peak } \\
\qquad\left(\Delta d_{\text {priv }}<\text { median }\left(\Delta d_{\text {priv }}\right)\right)\end{array}$ & $\begin{array}{l}-5.8^{*} \\
{[2.6]}\end{array}$ & $\begin{array}{l}-7.1^{* *} \\
{[2.2]}\end{array}$ & $\begin{array}{l}-6.9^{* *} \\
{[2.5]}\end{array}$ & $\begin{array}{l}-8.8^{* *} \\
{[2.3]}\end{array}$ \\
\hline $\begin{array}{l}\text { Financial peak } \\
\qquad\left(\Delta d_{\text {priv }}>\text { median }\left(\Delta d_{\text {priv }}\right)\right)\end{array}$ & $\begin{array}{c}-14.6^{* *} \\
{[5.2]}\end{array}$ & & $\begin{array}{c}-16.5^{* *} \\
{[3.7]}\end{array}$ & \\
\hline $\begin{array}{l}\text { Household financial peak } \\
\qquad\left(\Delta d_{\text {corp }}<\Delta d_{h h d}\right)\end{array}$ & & $\begin{array}{l}-18.1^{1 *} \\
{[5.1]}\end{array}$ & & $\begin{array}{c}-16.1^{* *} \\
{[4.9]}\end{array}$ \\
\hline $\begin{array}{l}\text { Corporate financial peak } \\
\qquad\left(\Delta d_{\text {corp }}>\Delta d_{h h d}\right)\end{array}$ & & $\begin{array}{l}-21.8^{* *} \\
{[5.4]}\end{array}$ & & $\begin{array}{l}-21.7^{* *} \\
{[3.0]}\end{array}$ \\
\hline Trade openness (at the peak) & $\begin{array}{c}5.2 \\
{[3.6]}\end{array}$ & $\begin{array}{c}5.3 \\
{[3.4]}\end{array}$ & $\begin{array}{l}7.1+ \\
{[3.9]}\end{array}$ & $\begin{array}{c}5.1 \\
{[4.0]}\end{array}$ \\
\hline Financial openness (at the peak) & $\begin{array}{c}0.17 \\
{[0.23]}\end{array}$ & $\begin{array}{c}0.07 \\
{[0.22]}\end{array}$ & $\begin{array}{l}-0.23 \\
{[0.25]}\end{array}$ & $\begin{array}{l}-0.3 \\
{[0.3]}\end{array}$ \\
\hline $\begin{array}{l}\text { World output growth } \\
\text { (2-year average following the peak) }\end{array}$ & $0.92+$ & $\begin{array}{l}0.90+ \\
{[0.45]}\end{array}$ & $\begin{array}{c}0.69 \\
{[0.48]}\end{array}$ & $\begin{array}{c}1.0^{*} \\
{[0.47]}\end{array}$ \\
\hline \multirow[t]{2}{*}{ Normal peak $\cdot$ Public debt-GDP ratio } & -4.0 & -0.7 & -0.8 & 4.4 \\
\hline & {$[6.2]$} & {$[5.3]$} & {$[6.1]$} & {$[5.6]$} \\
\hline \multirow[t]{2}{*}{ Normal peak $\cdot$ Public debt-GDP ratio, squared } & 0.38 & -0.62 & -0.81 & -2.4 \\
\hline & {$[2.6]$} & {$[2.5]$} & {$[2.5]$} & {$[2.5]$} \\
\hline \multirow[t]{2}{*}{ Financial peak $\cdot$ Public debt-GDP ratio } & 21.7 & & $27.1^{*}$ & \\
\hline & {$[15.4]$} & & {$[11.0]$} & \\
\hline \multirow[t]{2}{*}{ Financial peak $\cdot$ Public debt-GDP ratio, squared } & $-18.6+$ & & $-20.6^{*}$ & \\
\hline & {$[11.0]$} & & {$[7.8]$} & \\
\hline \multirow[t]{2}{*}{ Household fin peak - Public debt-GDP ratio } & & $33.9^{*}$ & & 23.4 \\
\hline & & {$[14.9]$} & & {$[16.1]$} \\
\hline
\end{tabular}

20 When we include the interactions with the linear term of the public debt-GDP ratio, their coefficients are not statistically significant. 


\begin{tabular}{|c|c|c|c|c|}
\hline \multirow[b]{3}{*}{ Variables } & \multicolumn{4}{|c|}{ Depth of Recession } \\
\hline & \multicolumn{2}{|c|}{ Advanced Economies } & \multicolumn{2}{|c|}{ Advanced and Emerging } \\
\hline & (1) & (2) & (3) & (4) \\
\hline \multirow[t]{2}{*}{ Household fin peak $\cdot$ Public debt-GDP ratio, squared } & & $-28.9^{*}$ & & -16.0 \\
\hline & & {$[11.2]$} & & [13.1] \\
\hline \multirow[t]{2}{*}{ Corporate fin peak $\cdot$ Public debt-GDP ratio } & & $43.8^{*}$ & & $45.9^{* *}$ \\
\hline & & {$[16.3]$} & & [9.0] \\
\hline \multirow[t]{2}{*}{ Corporate fin peak $\cdot$ Public debt-GDP ratio, squared } & & $-31.2^{*}$ & & $-31.7^{* *}$ \\
\hline & & {$[11.9]$} & & {$[6.8]$} \\
\hline $\mathrm{R}^{2}$ & 0.89 & 0.9 & 0.90 & 0.9 \\
\hline Observations, normal peaks & 32 & 32 & 45 & 45 \\
\hline Observations, financial peaks & 39 & & 52 & \\
\hline Observations, household fin peaks & & 16 & & 21 \\
\hline Observations, corporate fin peaks & & 18 & & 24 \\
\hline$p$-value (norm vs fin) & 0.06 & & 0.00 & \\
\hline$p$-value (norm vs HHD fin) & & 0.04 & & 0.14 \\
\hline$p$-value (norm vs corp fin) & & 0.01 & & 0.00 \\
\hline$p$-value (HHD fin vs corp fin) & & 0.44 & & 0.20 \\
\hline
\end{tabular}

(b) Consumption

\section{Depth of Recession}

\begin{tabular}{|c|c|c|c|c|}
\hline \multirow[b]{2}{*}{ Variables } & \multicolumn{2}{|c|}{ Advanced Economies } & \multicolumn{2}{|c|}{ Advanced and Emerging } \\
\hline & (1) & (2) & (3) & (4) \\
\hline \multirow{2}{*}{$\begin{array}{l}\text { Normal peak } \\
\quad\left(\Delta d_{\text {priv }}<\operatorname{median}\left(\Delta d_{\text {priv }}\right)\right)\end{array}$} & $-5.4^{*}$ & $-5.1+$ & $-4.6+$ & $-5.2+$ \\
\hline & {$[2.5]$} & {$[2.9]$} & {$[2.6]$} & {$[2.9]$} \\
\hline \multirow{2}{*}{$\begin{array}{l}\text { Financial peak } \\
\qquad\left(\Delta d_{\text {priv }}>\text { median }\left(\Delta d_{\text {priv }}\right)\right)\end{array}$} & $-11.0^{*}$ & & $-13.8^{* *}$ & \\
\hline & {$[4.9]$} & & [3.8] & \\
\hline \multirow{2}{*}{$\begin{array}{l}\text { Household financial peak } \\
\qquad\left(\Delta d_{\text {corp }}<\Delta d_{h h d}\right)\end{array}$} & & $-13.8^{*}$ & & $-14.2^{* *}$ \\
\hline & & {$[5.2]$} & & {$[4.7]$} \\
\hline Corporate financial peak & & -4.9 & & $-15.4^{*}$ \\
\hline$\left(\Delta d_{\text {corp }}>\Delta d_{h h d}\right)$ & & {$[5.6]$} & & {$[7.3]$} \\
\hline Trade openness (at the peak) & $\begin{array}{c}8.6 \\
{[5.5]}\end{array}$ & $\begin{array}{l}10.8+ \\
{[5.9]}\end{array}$ & $\begin{array}{c}6.4 \\
{[5.4]}\end{array}$ & $\begin{array}{c}5.7 \\
{[6.5}\end{array}$ \\
\hline Financial openness (at the peak) & $\begin{array}{c}0.59^{*} \\
{[0.25]}\end{array}$ & $\begin{array}{l}0.76+ \\
{[0.38]}\end{array}$ & $\begin{array}{c}0.44 \\
{[0.31]}\end{array}$ & $\begin{array}{c}0.57 \\
{[0.44]}\end{array}$ \\
\hline \multirow{2}{*}{$\begin{array}{l}\text { World output growth } \\
\text { (2-year average following the peak) }\end{array}$} & 1.01 & 0.94 & -0.19 & -0.20 \\
\hline & {$[0.61]$} & [0.62] & {$[0.89]$} & {$[0.95]$} \\
\hline \multirow[t]{2}{*}{ Normal peak $\cdot$ Public debt-GDP ratio } & -6.2 & -7.1 & -2.0 & 0.3 \\
\hline & {$[7.0]$} & {$[7.3]$} & {$[7.1]$} & {$[7.8]$} \\
\hline \multirow[t]{2}{*}{ Normal peak $\cdot$ Public debt-GDP ratio, squared } & 2.0 & 2.0 & 0.10 & -0.8 \\
\hline & {$[2.9]$} & {$[2.9]$} & {$[3.04]$} & {$[3.2]$} \\
\hline \multirow[t]{2}{*}{ Financial peak $\cdot$ Public debt-GDP ratio } & 12.8 & & $24.7^{\star}$ & \\
\hline & [14.8] & & [11.7] & \\
\hline \multirow[t]{2}{*}{ Financial peak $\cdot$ Public debt-GDP ratio, squared } & -11.6 & & $-18.3+$ & \\
\hline & {$[11.7]$} & & {$[9.2]$} & \\
\hline \multirow[t]{2}{*}{ Household fin peak $\cdot$ Public debt-GDP ratio } & & 19.5 & & 26.2 \\
\hline & & {$[17.1]$} & & {$[15.8]$} \\
\hline \multirow[t]{2}{*}{ Household fin peak $\cdot$ Public debt-GDP ratio, squared } & & -18.9 & & -20.2 \\
\hline & & [14.5] & & {$[13.6]$} \\
\hline \multirow[t]{2}{*}{ Corporate fin peak $\cdot$ Public debt-GDP ratio } & & -7.5 & & 28.2 \\
\hline & & [18.3] & & {$[22.9]$} \\
\hline
\end{tabular}


Table 8 continued

\begin{tabular}{|c|c|c|c|c|}
\hline \multirow[b]{3}{*}{ Variables } & \multicolumn{4}{|c|}{ Depth of Recession } \\
\hline & \multicolumn{2}{|c|}{ Advanced Economies } & \multicolumn{2}{|c|}{ Advanced and Emerging } \\
\hline & $(1)$ & (2) & (3) & (4) \\
\hline \multirow[t]{2}{*}{ Corporate fin peak $\cdot$ Public debt-GDP ratio, squared } & & 3.5 & & -18.1 \\
\hline & & {$[13.8]$} & & {$[16.3]$} \\
\hline $\mathrm{R}^{2}$ & 0.78 & 0.8 & 0.79 & 0.8 \\
\hline Observations, normal peaks & 32 & 32 & 45 & 45 \\
\hline Observations, financial peaks & 39 & & 52 & \\
\hline Observations, household fin peaks & & 16 & & 21 \\
\hline Observations, corporate fin peaks & & 18 & & 24 \\
\hline$p$-value (norm vs fin) & 0.26 & & 0.01 & \\
\hline$p$-value (norm vs HHD fin) & & 0.10 & & 0.05 \\
\hline$p$-value (norm vs corp fin) & & 0.97 & & 0.13 \\
\hline$p$-value (HHD fin vs corp fin) & & 0.08 & & 0.85 \\
\hline
\end{tabular}

(c) Investment

Depth of Recession

\begin{tabular}{|c|c|c|c|c|}
\hline \multirow[b]{2}{*}{ Variables } & \multicolumn{2}{|c|}{ Advanced Economies } & \multicolumn{2}{|c|}{ Advanced and Emerging } \\
\hline & (1) & (2) & (3) & (4) \\
\hline \multirow{2}{*}{$\begin{array}{l}\text { Normal peak } \\
\quad\left(\Delta d_{\text {priv }}<\text { median }\left(\Delta d_{\text {priv }}\right)\right) \\
\text { Financial peak } \\
\quad\left(\Delta d_{\text {priv }}>\text { median }\left(\Delta d_{\text {priv }}\right)\right)\end{array}$} & $\begin{array}{l}-23.8^{* *} \\
{[8.0]}\end{array}$ & $\begin{array}{l}-25.8^{* *} \\
{[9.3]}\end{array}$ & $\begin{array}{l}-26.7^{* *} \\
{[8.5]}\end{array}$ & $\begin{array}{l}-28.9^{* *} \\
{[9.4]}\end{array}$ \\
\hline & $\begin{array}{l}-49.6^{* *} \\
{[14.3]}\end{array}$ & & $\begin{array}{l}-63.6^{* *} \\
{[14.7]}\end{array}$ & \\
\hline $\begin{array}{l}\text { Household financial peak } \\
\qquad\left(\Delta d_{\text {corp }}<\Delta d_{h h d}\right)\end{array}$ & & $\begin{array}{l}-53.0^{* *} \\
{[16.7]}\end{array}$ & & $\begin{array}{l}-40.3^{*} \\
{[17.5]}\end{array}$ \\
\hline $\begin{array}{l}\text { Corporate financial peak } \\
\qquad\left(\Delta d_{\text {corp }}>\Delta d_{h h d}\right)\end{array}$ & & $\begin{array}{l}-77.8^{* *} \\
{[22.1]}\end{array}$ & & $\begin{array}{l}-77.9^{* *} \\
{[14.7]}\end{array}$ \\
\hline Trade openness (at the peak) & $\begin{array}{l}34.2+ \\
{[20.2]}\end{array}$ & $\begin{array}{l}40.0+ \\
{[21.8]}\end{array}$ & $\begin{array}{l}54.9^{*} \\
{[23.3]}\end{array}$ & $\begin{array}{l}43.7+ \\
{[24.8]}\end{array}$ \\
\hline Financial openness (at the peak) & $\begin{array}{c}-1.9+ \\
{[1.1]}\end{array}$ & $\begin{array}{l}-1.7 \\
{[1.4]}\end{array}$ & $\begin{array}{l}-2.8^{*} \\
{[1.3]}\end{array}$ & $\begin{array}{l}-2.0 \\
{[1.6]}\end{array}$ \\
\hline $\begin{array}{l}\text { World output growth } \\
\text { (2-year average following the peak) }\end{array}$ & $\begin{array}{c}1.3 \\
{[2.3]}\end{array}$ & $\begin{array}{c}1.3 \\
{[2.3]}\end{array}$ & $\begin{array}{c}1.1 \\
{[2.2]}\end{array}$ & $\begin{array}{c}2.6 \\
{[2.2]}\end{array}$ \\
\hline \multirow[t]{2}{*}{ Normal peak Public debt-GDP ratio } & 3.3 & 7.1 & 2.0 & 12.2 \\
\hline & {$[22.3]$} & [26.1] & {$[22.0]$} & {$[23.5]$} \\
\hline \multirow[t]{2}{*}{ Normal peak Public debt-GDP ratio, squared } & -4.5 & -5.7 & -4.3 & -7.7 \\
\hline & {$[10.0]$} & [11.2] & {$[9.5]$} & {$[9.9]$} \\
\hline \multirow[t]{2}{*}{ Financial peak $\cdot$ Public debt-GDP ratio } & $81.3+$ & & $113.4^{* *}$ & \\
\hline & {$[43.8]$} & & {$[42.1]$} & \\
\hline \multirow[t]{2}{*}{ Financial peak $\cdot$ Public debt-GDP ratio, squared } & $-59.5+$ & & $-81.4^{*}$ & \\
\hline & {$[34.6]$} & & [32.9] & \\
\hline \multirow[t]{2}{*}{ Household fin peak - Public debt-GDP ratio } & & $95.7+$ & & 33.5 \\
\hline & & {$[54.3]$} & & [57.9] \\
\hline \multirow[t]{2}{*}{ Household fin peak $\cdot$ Public debt-GDP ratio, squared } & & $-79.1+$ & & -23.1 \\
\hline & & {$[44.7]$} & & {$[49.5]$} \\
\hline \multirow[t]{2}{*}{ Corporate fin peak $\cdot$ Public debt-GDP ratio } & & $163.6^{*}$ & & $164.6^{* *}$ \\
\hline & & $\begin{array}{l}{[68.3]} \\
-108.8^{*}\end{array}$ & & $\begin{array}{l}{[45.7]} \\
-111.2^{* *}\end{array}$ \\
\hline Corporate fin peak $\cdot$ Public debt-GDP ratio, squared & & {$[47.3]$} & & {$[33.4]$} \\
\hline
\end{tabular}




\begin{tabular}{|c|c|c|c|c|}
\hline \multirow[b]{3}{*}{ Variables } & \multicolumn{4}{|c|}{ Depth of Recession } \\
\hline & \multicolumn{2}{|c|}{ Advanced Economies } & \multicolumn{2}{|c|}{ Advanced and Emerging } \\
\hline & (1) & $(2)$ & (3) & (4) \\
\hline$R^{2}$ & 0.83 & 0.85 & 0.83 & 0.82 \\
\hline Observations, normal peaks & 32 & 32 & 45 & 45 \\
\hline Observations, financial peaks & 39 & & 52 & \\
\hline Observations, household fin peaks & & 16 & & 21 \\
\hline Observations, corporate fin peaks & & 18 & & 24 \\
\hline$p$-value (norm vs fin) & 0.06 & & 0.01 & \\
\hline$p$-value (norm vs HHD fin) & & 0.11 & & 0.52 \\
\hline$p$-value (norm vs corp fin) & & 0.02 & & 0.00 \\
\hline$p$-value (HHD fin vs corp fin) & & 0.17 & & 0.04 \\
\hline
\end{tabular}

$\mathrm{GDP}=$ gross domestic product, $\mathrm{HHD}=$ household .

Notes:

1. The dependent variable is the depth of recessions in output defined by the average percentage change in GDP per capita from a peak to the next trough. A constant term is not included as a regressor.

2. The sample comprises both the advanced and emerging market economies listed in Appendix Table A1.

3. Normal, household financial, and corporate financial peaks are dummy variables that take the value of 1 if the peak is normal, household financial, and corporate financial, respectively, and zero otherwise.

4. Trade openness is defined as the sum of exports and imports divided by GDP. Financial openness is defined as the sum of external total assets and liabilities divided by GDP.

5. The reported $p$-values, (norm vs HHD fin), (norm vs corp fin), and (HHD fin vs corp fin) are for the test for equality of coefficients of normal versus household financial peaks, normal versus corporate financial peaks, and household versus corporate financial peaks, respectively.

6. Numbers in brackets are robust standard errors.

7. **, *, and + denote significance levels of $1 \%, 5 \%$, and $10 \%$, respectively.

Source: Authors' calculations.

In Table 8, column 3 of panel (a), if the sample includes EMEs, the interaction term of the financial peak with the square of the public debt-GDP ratio is statistically significant even at the $1 \%$ level, while the corresponding interaction term for the normal peak is statistically insignificant. In column 4, when we distinguish between household and corporate financial peaks, only the interaction term between the corporate peak and the public debt-GDP ratio is statistically significant at the $1 \%$ level.

Figure 2 shows this nonlinear effect of fiscal space by plotting the relationship between the public debt-GDP ratio and the depth of recessions. In the upper panel, we present this relationship for AEs. The solid dots and x's represent financial and normal recessions, respectively. Although there is generally an inverted U-shape relationship, particularly for financial recessions, this relationship is mainly driven by outliers, such as Greece. For all economies in the sample (Figure 2, panel [b]), the inverted $U$-shape is more evident. Panel (c) plots the relationship for EMEs. Because financial debt data are not available for EMEs and hence normal and financial peaks are not distinguishable, the inverted U-shape is the most clearly visible. Overall, we conclude that the nonlinear impact of fiscal space on the depth of recessions is more visible for corporate financial recessions, particularly in EMEs. 
Figure 2: Ratio of Public Debt to Gross Domestic Product versus Depth of Recession in Output, Interest Rate, and Cyclical Credit

(a) Advanced economies

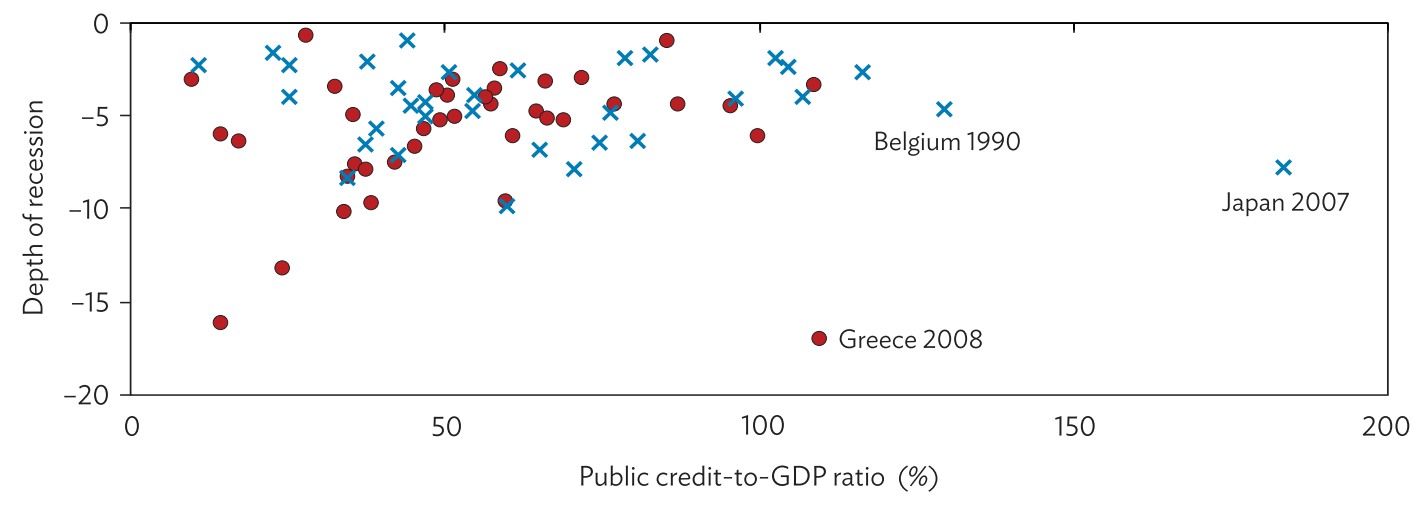

(b) Advanced and emerging market economies

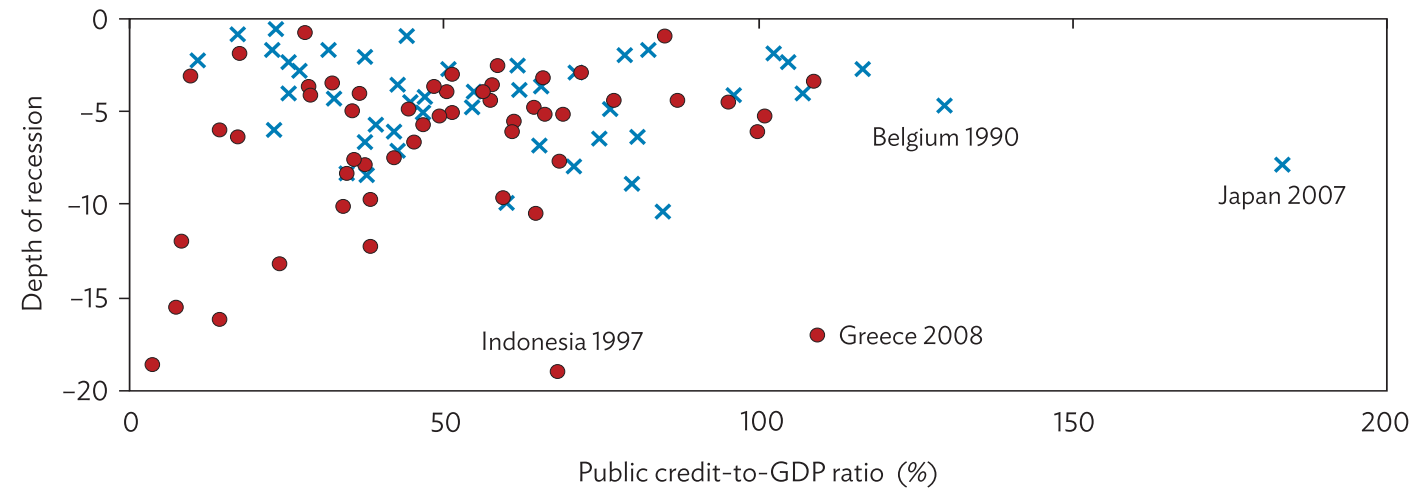

(c) Emerging market economies

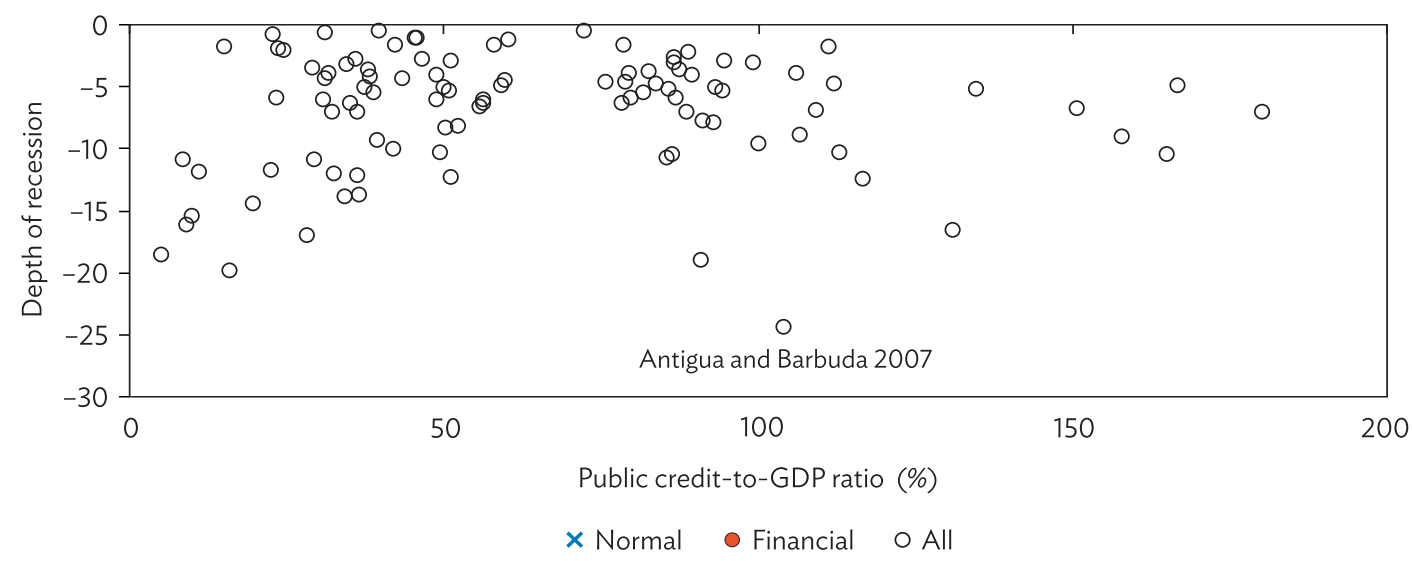

GDP = gross domestic product.

Notes:

1. Depth of recessions in output is measured by calculating annual percentage changes from the peak of cyclical parts of GDP to the next trough.

2. Financial debt data are not available in many emerging market economies; hence, normal and financial peaks are not distinguishable.

3. Appendix Table A1 lists the advanced and emerging market economies.

Source: Authors' calculations. 
Table 8, panel (b), shows the same regression results using the depth of consumption recessions as the dependent variable. We generally find much less evidence on the benefits of fiscal space. If the sample includes all economies, however, the interaction between the financial peak and the public debt-GDP ratio becomes statistically significant at the $10 \%$ level. Panel (c) shows the same regression results using the depth of investment recessions as the dependent variable. In columns 1 and 2, which show the results for AEs, the interaction term between the financial peak (but not the normal peak) and the public debt-GDP ratio is significant at the $10 \%$ level. The interactions of household and corporate financial peaks with public debt-GDP ratio are significant at either the 5\% or $10 \%$ levels. In columns 3 and 4 , if we extend the sample to EMEs, we find even stronger evidence of the nonlinear effects of fiscal space, especially for corporate financial recessions. Hence, our results suggest again that the nonlinear effect of fiscal space is stronger for EMEs, particularly for corporate financial recessions.

\section{CONCLUSION}

This paper empirically investigates the relationship between the buildup of private debt, which consists of household debt and corporate debt, and the depth of recessions. We divide recessions into two types, financial and normal recessions, based on the speed of accumulation of private debt. More specifically, if the annual percentage increase in the buildup of private debt before peaks exceeds the sample median, then the ensuing recessions are defined as financial recessions and otherwise as normal recessions. As a robustness check, we use quartiles of the speed of private debt buildup to define normal versus financial recessions. Most studies define financial recessions as those coinciding with financial crises. Our definition of financial recessions, however, includes financial recessions that do not coincide with financial crises, our analysis examines and compares financial recessions that coincide with crises and those that do not. We also examine the effect that the level of public debt has on financial and normal recessions.

We find that the financial recessions are severer than normal recessions in terms of output and investment at statistically significant levels in both AEs and EMEs. This is in line with the literature, which generally finds that financial recessions are more pronounced than other types of recessions. But we find much less evidence that financial consumption recessions are deeper than normal consumption recessions in AEs. When EMEs are included in the sample, we find some evidence even for consumption that financial recessions are deeper. This finding is even stronger if we define financial recessions based on quartiles. While somewhat weaker, the findings also generally hold for financial recessions that do not coincide with crises.

When we further distinguish between financial recessions that are driven by household and corporate debt buildups, we find that recessions driven by household debt buildups are generally deeper than recessions driven by corporate debt buildups in AEs. This is consistent with the literature. But when we include EMEs, recessions driven by corporate debt recessions are deeper than household debt recessions in some specifications, suggesting that corporate debt buildups are especially damaging to EMEs. We find that the public debt-GDP ratio, a measure of fiscal space, exacerbates recessions only after it reaches a threshold level of $57.9 \%$. This effect is only for financial recessions, suggesting that fiscal policy is more relevant for responding to financial distress. We find that the nonlinear effect of fiscal space is more evident in EMEs, and that fiscal space is more useful in tackling corporate debt recessions. 
Overall, our evidence is consistent with the literature in that it shows that financial recessions inflict more damage on the real economy than normal recessions. While most studies on the nexus between financial instability and recessions look at financial crises or asset price busts, we add to this literature by examining an alternative measure of financial instability: the speed of private debt buildup. Here, we find that recessions associated with a rapid buildup of private debt tend to be deeper than those associated with a slower buildup. Expanding the sample to include EMEs does not qualitatively change the results, which are also robust to more restrictive definitions of financial recessions. Our findings suggest that private debt buildups can be harbingers of deep recessions. 


\section{APPENDIX}

Table A1: Advanced and Emerging Market Economies Used in the Sample

\begin{tabular}{ll}
\hline Advanced & Emerging \\
\hline Australia & Argentina \\
Austria & Brazil \\
Belgium & Colombia \\
Canada & Czech Republic \\
Denmark & Hong Kong, China \\
Finland & Hungary \\
France & Indonesia \\
Germany & Israel \\
Greece & Malaysia \\
Ireland & Mexico \\
Italy & Poland \\
Japan & Republic of Korea \\
Netherlands & Russian Federation \\
New Zealand & Saudi Arabia \\
Norway & Singapore \\
Portugal & Thailand \\
Spain & Turkey \\
Sweden & \\
Switzerland & \\
United Kingdom & \\
United States & \\
\hline Source: Authors' compilation. & \\
\hline
\end{tabular}


Table A2: Definitions of Variables and Data Sources

\begin{tabular}{|c|c|c|}
\hline Variables & Description & Data Source \\
\hline $\begin{array}{l}\text { Private credit-to-GDP ratio, } \\
\text { 1960-2016 }\end{array}$ & $\begin{array}{l}\text { Total credit of private nonfinancial sector divided by } \\
\text { GDP, in market value, adjusted for breaks ( } \% \text { of GDP) }\end{array}$ & BIS total credit statistics \\
\hline $\begin{array}{l}\text { Household credit-to-GDP ratio, } \\
\text { 1960-2016 }\end{array}$ & $\begin{array}{l}\text { Total credit of households and nonprofit institutions } \\
\text { serving households divided by GDP, in market value, } \\
\text { adjusted for breaks (\% of GDP) }\end{array}$ & BIS total credit statistics \\
\hline $\begin{array}{l}\text { Corporate credit-to-GDP ratio, } \\
\text { 1960-2016 }\end{array}$ & $\begin{array}{l}\text { Total credit of nonfinancial corporations divided by } \\
\text { GDP, in market value, adjusted for breaks ( } \% \text { of GDP) }\end{array}$ & BIS total credit statistics \\
\hline $\begin{array}{l}\text { Public credit-to-GDP ratio, } \\
\text { 1960-2016 }\end{array}$ & $\begin{array}{l}\text { Total credit of general government (central } \\
\text { government if collected from BIS or WDI) divided by } \\
\text { GDP, in market value (\% of GDP) }\end{array}$ & $\begin{array}{l}\text { BIS total credit statistics; } \\
\text { WDI data; and World } \\
\text { Economic Outlook }\end{array}$ \\
\hline $\begin{array}{l}\text { Real output per capita, } \\
\text { 1960-2014 }\end{array}$ & $\begin{array}{l}\text { Per capita real GDP at constant } 2011 \text { national prices } \\
\text { divided by population (in } 2011 \text { dollars) }\end{array}$ & Penn World Table 9.0 \\
\hline $\begin{array}{l}\text { Real consumption per capita, } \\
\text { 1960-2014 }\end{array}$ & $\begin{array}{l}\text { Share of household consumption at current PPPs } \\
\text { times output-side real GDP at chained PPPs divided } \\
\text { by population (in } 2011 \text { dollars) }\end{array}$ & Penn World Table 9.0 \\
\hline $\begin{array}{l}\text { Real investment per capita, } \\
\text { 1960-2014 }\end{array}$ & $\begin{array}{l}\text { Share of gross capital formation at current PPPs times } \\
\text { output-side real GDP at chained PPPs divided by } \\
\text { population (in } 2011 \text { dollars) }\end{array}$ & Penn World Table 9.0 \\
\hline Housing prices, 1950-2013 & $\begin{array}{l}\text { Index of housing prices } \\
\text { (JST: } 1990=100 \text { and BIS: baseline year varies) }\end{array}$ & $\begin{array}{l}\text { BIS residential property } \\
\text { price database, } \\
\text { Jordà-Schularick-Taylor } \\
\text { Macrohistory Database }\end{array}$ \\
\hline Stock prices, 1950-2014 & Index of stock prices $(1990=100)$ & $\begin{array}{l}\text { Jordà-Schularick-Taylor } \\
\text { Macrohistory Database, } \\
\text { Global Financial Data, and } \\
\text { Bloomberg }\end{array}$ \\
\hline Trade openness, 2010 and 2007 & $\begin{array}{l}\text { Sum of exports and imports of goods and services } \\
\text { measured as a share of GDP (\% of GDP) }\end{array}$ & WDI \\
\hline Financial openness, 1970-2011 & $\begin{array}{l}\text { Total foreign assets plus total foreign liabilities as a } \\
\text { share of GDP ( } \% \text { of GDP) }\end{array}$ & $\begin{array}{l}\text { Lane and Milesi-Ferretti } \\
\text { dataset }\end{array}$ \\
\hline World growth, 1962-2016 & $\begin{array}{l}\text { Percentage growth rate of world aggregate GDP } \\
\text { ( } 2010 \text { constant dollars) without deductions for } \\
\text { depreciation of assets or for degradation of natural } \\
\text { resources }\end{array}$ & WDI \\
\hline
\end{tabular}

BIS = Bank for International Settlements, GDP = gross domestic product, JST = Jordà-Schularick-Taylor, PPP = purchasing power parity, $\mathrm{WDI}=$ World Development Indicators.

Source: Authors' compilation. 


\section{REFERENCES}

Bernardini, Marco, and Lorenzo Forni. 2017. "Private and Public Debt: Are Emerging Markets at Risk?" IMF Working Paper No. WP/17/61. Washington, DC: International Monetary Fund.

Bry, Gerhard, and Charlotte Boschan. 1971. Cyclical Analysis of Time Series: Selected Procedures and Computer Programs. New York: National Bureau of Economic Research.

Cecchetti, Stephen G., Madhusudan Mohanty, and Fabrizio Zampolli. 2011. "The Real Effects of Debt." BIS Working Papers No. 352. Basel: Bank for International Settlements.

Claessens, Stijn, M. Ayhan Kose, and Marco E. Terrones. 2012. "How Do Business and Financial Cycles Interact?” Journal of International Economics 87 (1): 178-90

Jordà, Òscar, Moritz Schularick, and Alan M. Taylor. 2013. "When Credit Bites Back." Journal of Money, Credit and Banking Supplement 45 (2): 3-28.

Kose, M. Ayhan, Eswar Prasad, and Marco Terrones. 2006. "How Do Trade and Financial Integration Affect the Relationship between Growth and Volatility?" Journal of International Economics 69 (1): 176-202.

Mian, Atif, Amir Sufi, and Emil Verner. 2017. "Household Debt and Business Cycles Worldwide." The Quarterly Journal of Economics 132 (4): 1755-817.

Park, Donghyun, Kwanho Shin, and Shu Tian. 2018. "Household Debt, Corporate Debt, and Economic Growth: Some Empirical Evidence.” ADB Economics Working Paper Series No. 567. Manila: Asian Development Bank.

Romer, Christina D., and David H. Romer. 2017a. "New Evidence on the Aftermath of Financial Crises in Advanced Countries." American Economic Review 107 (10): 3072-118.

2017b. "Why Some Times Are Different: Macroeconomic Policy and the Aftermath of Financial Crisis." NBER Working Paper No. 23931. Cambridge, MA: National Bureau of Economic Research. 


\section{Debt and Depth of Recessions}

This paper empirically investigates the relationship between the speed of the buildup of private debthousehold and corporate debt-and the depth of recessions. To do this, it differentiates between financial recessions and normal recessions on the basis of the speed of the debt buildup. It finds that financial recessions are deeper than normal recessions in advanced economies and that the differences become more pronounced when emerging market economies are added to the sample. It finds that the buildup of corporate debt-and not just household debt-can worsen recessions, especially in emerging market economies.

\section{About the Asian Development Bank}

ADB is committed to achieving a prosperous, inclusive, resilient, and sustainable Asia and the Pacific, while sustaining its efforts to eradicate extreme poverty. Established in 1966, it is owned by 68 members -49 from the region. Its main instruments for helping its developing member countries are policy dialogue, loans, equity investments, guarantees, grants, and technical assistance. 